\title{
Sea surface temperature across the Subarctic North Pacific and marginal seas through the past 20,000 years: A paleoceanographic synthesis
}

\author{
Catherine V. Davis ${ }^{a, 3, *}$, Sarah E. Myhre ${ }^{b, c}$, Curtis Deutsch ${ }^{c}$, Beth Caissie ${ }^{d}$, \\ Summer Praetorius ${ }^{e}$, Marisa Borreggine ${ }^{c, 1}$, Robert Thunell ${ }^{\text {a, }}{ }^{2}$ \\ a School of Earth, Oceans, And the Environment, University of South Carolina, 701 Sumter St, Columbia, SC, USA \\ ${ }^{\mathrm{b}}$ Future of Ice Initiative, University of Washington, 1492 NE Boat St., Seattle, WA, 98105, USA \\ c School of Oceanography, University of Washington, 1503 NE Boat St., Seattle, WA, 98105, USA \\ ${ }^{\mathrm{d}}$ Department of Geological and Atmospheric Sciences, Iowa State University, 253 Science, Ames, IA, 50011, USA \\ e U.S. Geological Survey, 345 Middlefield Rd, Menlo Park, CA, 94025, USA
}

\section{A R T I C L E I N F O}

\section{Article history:}

Received 13 May 2019

Received in revised form

28 February 2020

Accepted 23 July 2020

Available online $\mathrm{xxx}$

\section{Keywords:}

Sea surface temperature

North Pacific

Bering sea

Sea of Okhotsk

Deglaciation

\begin{abstract}
A B S T R A C T
Deglacial sea surface conditions in the subarctic North Pacific and marginal seas are the subject of increasing interest in paleoceanography. However, a cohesive picture of near-surface oceanography from which to compare inter and intra-regional variability through the last deglaciation is lacking. We present a synthesis of sea surface temperature covering the open North Pacific and its marginal seas, spanning the past $20 \mathrm{ka}$ using proxy records from foraminiferal calcite $\left(\delta^{18} \mathrm{O}\right.$ and $\left.\mathrm{Mg} / \mathrm{Ca}\right)$ and coccolithophore alkenones $\left(\mathrm{U}^{\mathrm{k}^{\prime}}{ }_{37}\right)$. Sea surface temperature proxies tend to be in agreement through the Holocene, though $\mathrm{U}^{\mathrm{k}^{\prime}}{ }_{37}$ records are often interpreted as warmer than adjacent $\delta^{18} \mathrm{O}$ or $\mathrm{Mg} / \mathrm{Ca}$ records during the Last Glacial Maximum and early deglaciation. In the Sea of Okhotsk, Holocene discrepancies between $\delta^{18} \mathrm{O}$ and $\mathrm{U}^{\mathrm{k}^{\prime}}{ }_{37}$ may be the result of changes in near-surface stratification. We find that sea-surface warming occurred prior to the onset of the Bølling-Allerød ( $14.7 \mathrm{ka}$ ) and coincident with the onset of the Holocene (11.7 ka) in much of the North Pacific and Bering Sea. Proxy records also show a cold reversal roughly synchronous with the Younger Dryas (12.9-11.7 ka). After the onset of the Holocene, the influence of an intensified warm Kuroshio Current is evident at higher latitudes in the Western Pacific, and an east-west seesaw in sea surface temperature, likely driven by changes in the strength of the North Pacific Gyre, characterizes the open interglacial North Pacific.
\end{abstract}

๑) 2020 Elsevier Ltd. All rights reserved.

\section{Introduction}

The last deglaciation is characterized in the North Atlantic by discrete intervals of temperature change, in particular abrupt warming at the onset of the Bølling-Allerød (14.7 ka), a cold reversal in the Younger Dryas (12.9-11.7 ka), and another abrupt warming at the onset of the Holocene (11.7 ka) (Clark et al., 2012; Rasmussen et al., 2015). Records of deglacial near-surface changes in the North Pacific, including sea surface temperature (SST), are

\footnotetext{
* Corresponding author.

E-mail address: cvdavis@seoe.sc.edu (C.V. Davis).

1 Present Address: Harvard, Cambridge, MA, 02138, USA

2 Deceased: July 30, 2018.

3 Present Address: Yale University, New Haven, CT 06511
}

less well constrained. Along the Eastern Pacific margin, temperature changes associated with the Bølling-Allerød, Younger Dryas, and Holocene are roughly analogous to and synchronous with those recorded in the North Atlantic (e.g., Hendy and Kennett, 1999; Kiefer et al., 2001; Praetorius et al., 2015), while also demonstrating features of the deglaciation similar to a Southern Hemisphere pattern of warming (e.g., Kiefer and Kienast, 2005; Hill et al., 2006). However, less consistency has been seen in the interpretation of SST records from the Western North Pacific. The timing of North Pacific termination events remains unresolved in the Bering Sea (Seki et al., 2002; Kiefer and Kienast, 2005; Sarnthein et al., 2006; Schlung et al., 2013), though synchronicity with Greenland is evident in some records (e.g., Kuehn et al., 2014). By contrast, Sea of Okhotsk records display a markedly different deglacial history from the rest of the North Pacific (Harada et al., 2012). 
A comprehensive understanding of deglacial trends in the North Pacific and marginal seas is essential for understanding orbital and millennial climate variability. Here we utilize the database of available North Pacific records from Borreggine et al. (2017) to generate a synthesis of SST evolution from the Eastern and Western North Pacific, Bering Sea, and Sea of Okhotsk. We draw upon previous works and attempt to reconcile existing biotic proxy records from the $\mathrm{U}^{\mathrm{k}^{\prime}}{ }_{37}$ index, $\mathrm{Mg} / \mathrm{Ca}$, and $\delta^{18} \mathrm{O}$, across the mid- and highlatitude North Pacific (above $35^{\circ} \mathrm{N}$ ) and marginal seas. Integrating these disparate datasets allows for the identification of basin- and ocean-scale trends in SST over the last $20 \mathrm{ka}$, and highlights intra- and inter-regional variability and differences between proxy approaches.

This synthesis will address (1) which major features (including expressions of Heinrich Stadial 1, the Bølling-Allerød, and the Younger Dryas) characterize deglacial warming in records from the mid- and high-latitude North Pacific and marginal basins; (2) where regional (sub-basin scale) or biological (proxy) processes obscure broader patterns in deglacial SST; and (3) the identification of both basin- and ocean-scale trends in SST over the last $20 \mathrm{ka}$.

\subsection{Modern North Pacific and marginal seas}

\subsubsection{Eastern North Pacific}

In the Eastern North Pacific, the Alaskan Gyre is bounded to the north, east, and west by the cyclonic Alaska Current (Fig. 1). Modern SSTs in the Alaskan Gyre range from 15 to $18{ }^{\circ} \mathrm{C}$ in the summer to $3-8{ }^{\circ} \mathrm{C}$ in the winter (NOAA/PMEL, last accessed 01/20/2019). Seasonal changes also affect the Alaskan Gyre mixed layer depth which ranges from 10 s of meters $(\mathrm{m})$ in the summer to $\sim 100 \mathrm{~m}$ in the winter, driven in part by winter storm mixing (Childers et al., 2005; Pelland et al., 2016). South of the Alaskan Gyre the West Wind Drift divides into the northward flowing Alaska Current and southward flowing California Current, the Eastern boundary current of the Pacific Subtropical Gyre.

\subsubsection{Western North Pacific}

The cyclonic Western Subarctic Gyre is bounded by the Oyashio Current to the west and the Aleutian Islands to the north (Fig. 1). Modern hydrographic measurements show surface temperatures that range between 15 and $17{ }^{\circ} \mathrm{C}$ in the summer and $2-5^{\circ} \mathrm{C}$ in the winter (Harrison et al., 2004; Mochizuki et al., 2002). A strong halocline contributes to stratification in the region with a mixed layer $80-100 \mathrm{~m}$ deep in the winter and as shallow as $5-10 \mathrm{~m}$ in the summer (Tsurushima et al., 2002). Below the surface halocline is a temperature minimum, or dicothermal layer, with year-round stable temperatures below $3.5^{\circ} \mathrm{C}$ (Miura et al., 2002). To the south the Kuroshio Current, the Western boundary current of the North Pacific Subtropical Gyre, flows adjacent to the Japan Margin.

\subsubsection{Bering Sea}

The Bering Sea is partially enclosed by Alaska and Russia to the east and west and consists of a large shallow shelf region and the deep Aleutian Basin in the southwest (Fig. 1). Water exchange with the open North Pacific occurs across the Aleutian Island arc, primarily through the western passes (Stabeno et al., 2009). Summer surface circulation is cyclonic, and near surface waters are generally $5-9{ }^{\circ} \mathrm{C}$ and relatively fresh to a depth of around $30 \mathrm{~m}$ (Roden, 1995). Underlying this surface layer is a dicothermal layer, which is potentially a remnant of dense winter waters (Roden, 1995). At present, sea ice extends across much of the continental shelf in winter (Li and Wang, 2014), and the seasonal formation of sea ice produces cold, saline waters, which pass through the Bering Strait to the north, thereby interacting with the Atlantic as well as the Pacific Ocean (Stabeno et al., 2009).

\subsubsection{Sea of Okhotsk}

The Sea of Okhotsk is located between mainland Russia and the Kuril Islands, and is connected to the Western North Pacific through the Kuril Straits and the Sea of Japan (Fig. 1). The Sea of Okhotsk is the southernmost site of seasonal sea ice formation in the modern ocean, driven primarily by cold winter winds. In the absence of sea ice, a thin layer of warm (up to $15-20^{\circ} \mathrm{C}$ ) surface water overlies a dicothermal layer (Locarnini et al., 2013; Talley, 1991). The formation of winter sea ice along the northwestern shelf produces Dense Shelf Water, which in turn contributes to Okhotsk Sea Intermediate Water (Martin et al., 1998; Talley, 1991, 1993). At present this water mass is the principal contributor to North Pacific Intermediate Water upon leaving the Sea of Okhotsk through the Kuril Straits (Talley, 1991, 1993; Warner et al., 1996).

\section{Methods and materials}

\subsection{Site and sediment descriptions}

While our focus is on the subarctic Pacific, sediment core records have been included from as far south as $35^{\circ} \mathrm{N}$ to encompass the interface between the subarctic Pacific and the North Pacific gyre. Only cores with published age models developed by radiocarbon $\left({ }^{14} \mathrm{C}\right)$ dating were included in this synthesis, with some age models including tie points from foraminiferal $\delta^{18} \mathrm{O}$ (Table 1 ). Where multiple age models or revisions have been published, we relied on the most recent available literature. In most cases where ${ }^{14} \mathrm{C}$ dating was used but not calibrated to Intcal13 (Reimer et al., 2013), we updated these age models using rBacon (Blaauw and Christen, 2011) assuming a static surface reservoir age of 700 years. Where both $\delta^{18} \mathrm{O}$ and ${ }^{14} \mathrm{C}$ were used to develop an original age model, only ${ }^{14} \mathrm{C}$ tie points were retained in an effort to prevent a biasing of timing to known events. In some cases, published data were insufficient to update age models, in which cases temperature proxies are presented as originally dated (Table 1 ), and we do not attempt to directly compare the timing of events from these cores.

\subsection{Temperature proxies}

Temperature estimates were based on records of $\mathrm{U}^{\mathrm{k}^{\prime}} 37, \mathrm{Mg} / \mathrm{Ca}$, and $\delta^{18} \mathrm{O}$, the first of which is derived from coccolithophore alkenones, and the latter two from the calcium carbonate tests of planktic foraminifera. Most temperatures based on the $\mathrm{U}^{\mathrm{k}^{\prime}}{ }_{37}$ alkenone index are represented here as originally interpreted and published, except for where multiple records were available based on differing $\mathrm{U}^{\mathrm{k}^{\prime}}{ }_{37}$-temperature relationships. In these cases, we derived SSTs using the relationship of Sikes and others (1997). This relationship was chosen based on previous work in the Bering Sea showing that this calibration is preferable at cold temperatures (Méheust et al., 2013), although we note that most published records rely on the calibrations published by Prahl et al. (1998) or Müller et al. (1998) (Table 1) and that in general the callibration of Sikes et al. (1997) results in higher SST. Alkenone-based temperatures represent fall or late summer SST in the high-latitude North Pacific (Bae et al., 2014; Caissie et al., 2010; Haug et al., 2005; Pagani, 2002), while the planktic foraminifers Globigerina bulloides and Neogloboquadrina pachyderma record temperatures in the mixed layer and sub-thermocline $(\sim 30-200 \mathrm{~m})$ respectively with comparable seasonality (see Supplemental Text). Temperatures from the $\mathrm{Mg} / \mathrm{Ca}$ of the planktic foraminifera $N$. pachyderma have been adjusted to more closely approximate SST by a uniform offset of $5{ }^{\circ} \mathrm{C}$ to account for the subsurface habitat of this species. The correction applied is based upon the offset of $5^{\circ} \mathrm{C}$ from SST found in $\delta^{18} \mathrm{O}$ derived temperatures from Sea of Okhotsk $N$. pachyderma 

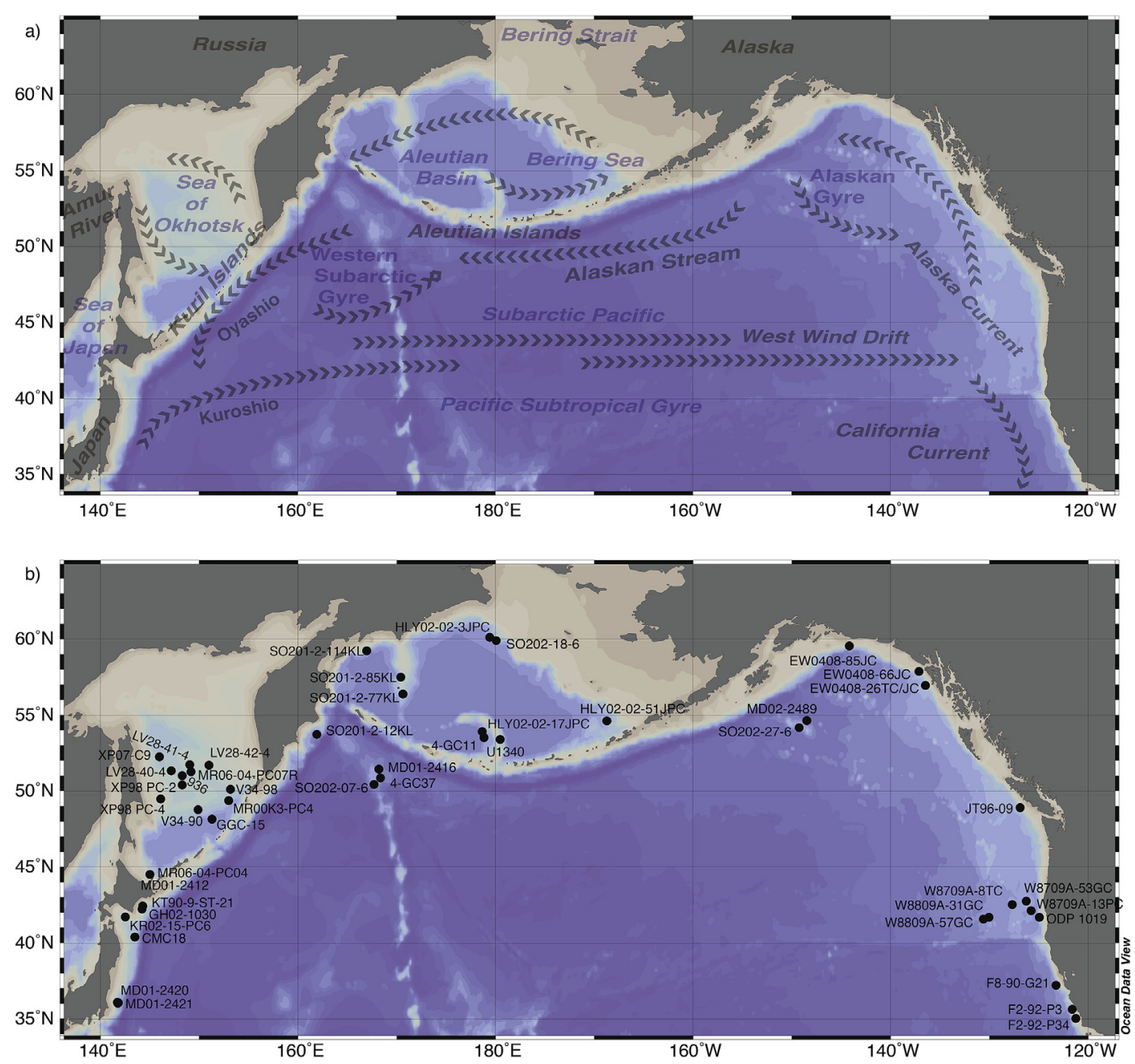

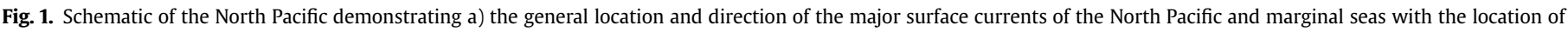
named currents after the Drifter-Derived Climatology of Global Near-Surface Currents (Laurindo et al., 2017) and b) core locations for all records included in this synthesis.

(Alderman, 1996), and allows $\mathrm{Mg} / \mathrm{Ca}$ temperatures to be integrated with $\mathrm{U}^{\mathrm{k}^{\prime}}$ 37 records. In both cases where a correction is applied (MD02-2489, MD01-2416) the result is comparable temperatures to nearby $\mathrm{U}^{\mathrm{k}^{\prime}} 37$ records during warm intervals. No offset was applied to $\mathrm{Mg} / \mathrm{Ca}$ from $\mathrm{G}$. bulloides shells in MD01-2420, based on the findings of the authors that $\mathrm{G}$. bulloides $\mathrm{Mg} / \mathrm{Ca}$ at this site represents near-surface temperatures (Sagawa et al., 2006).

To derive temperature from the $\delta^{18} \mathrm{O}$ of foraminifera tests, it is necessary to account for $\delta^{18} \mathrm{O}_{\text {seawater }}$, which is influenced by salinity and ice volume. Therefore, cores with both $\delta^{18} \mathrm{O}$ and another SST proxy $\left(\mathrm{U}^{\mathrm{k}^{\prime}}{ }_{37}\right.$ or $\mathrm{Mg} / \mathrm{Ca}$ ) were used to develop regional records of $\delta^{18} \mathrm{O}_{\text {seawater }}$ (Supplementary Fig. 1) from the generalized calcite temperature relationship of Shackleton (1974): $\mathrm{T}=16.9-4.38\left(\delta^{18} \mathrm{O}_{\text {calcite }}-\delta^{18} \mathrm{O}_{\text {seawater }}\right)+0.1\left(\delta^{18} \mathrm{O}_{\text {calcite }}-\delta^{18} \mathrm{O}_{\text {sea- }}\right.$ water). This equation was chosen to maintain consistency between sites reliant on $\delta^{18} \mathrm{O}$ temperatures from $G$. bulloides (for which species-specific $\delta^{18} \mathrm{O}$ equations are available), $N$. pachyderma (for which they are not), and mixed-species samples. Paired $\mathrm{U}^{\mathrm{k}^{\prime}} 37$ and $\delta^{18} \mathrm{O}_{\text {calcite }}$ were used from Bering Sea core U1340 and from Sea of Okhotsk core GGC-15. Paired $\delta^{18} \mathrm{O}_{\text {calcite }}$ and $\mathrm{Mg} / \mathrm{Ca}$ were used from Western North Pacific core MD01-2420 (Supplementary Fig. 2). By using $\mathrm{U}^{\mathrm{k}^{\prime}}{ }_{37}$ or $\mathrm{Mg} / \mathrm{Ca}$ to solve for the temperature variable, these multi-proxy records generate a regionally-specific $\delta^{18} \mathrm{O}_{\text {seawater }}$ curve, accounting simultaneously for changes in global ice volume, as well as spatial and temporal patterns in salinity (Supplementary
Fig. 1). Regional $\delta^{18} \mathrm{O}_{\text {seawater }}$ corrections were assumed to additionally encompass corrections for offsets in temperature due to calcification depth (Supplemental Table 1). This regional $\delta^{18} \mathrm{O}_{\text {sea- }}$ water curve can then be used to solve for the temperature component of $\delta^{18} \mathrm{O}$ in neighboring $\delta^{18} \mathrm{O}$ records (Supplemental Fig. 1 ), although it should be noted that limitations in the number of paired records available means that regional $\delta^{18} \mathrm{O}_{\text {seawater }}$ curves cover a large area, and are therefore an incomplete correction for the amount of variability due to salinity impacting any given site. The resulting records of temperature from site-specific $\delta^{18} \mathrm{O}_{\text {calcite }}$ records and regional $\delta^{18} \mathrm{O}_{\text {seawater }}$ curves are hereafter referred to as $\delta^{18} \mathrm{O}_{\text {temp. }}$

Temperatures were plotted for each region relative to latitude and age. To account for records of varying resolution and the presence of uncertainties within and between age models, interpolations were plotted at a 100-year resolution, and linear interpolation was applied between data points. In presentation of all regional data, locally regressed ('loess') trend lines have been overlaid along with bootstrapped confidence intervals. This data treatment is intended to allow for comparison between records with differing sample resolutions and age models while highlighting areas of inconsistency between regional records. 
Table 1

Sediment cores selected for temperature reconstructions, along with citations for the original source of data for SST proxies and age models. A column is also included indicating whether the age model presented here has been revised based on original AMS 14C (R), presented as originally published due to insufficient data (OID), or presented as originally published with no update needed (OUD). Basic data about the length, sampling resolution and sedimentation rate (range or average) is also presented where available (Borreggine et al., 2017).

\begin{tabular}{|c|c|c|c|c|c|c|c|c|}
\hline $\begin{array}{l}\text { Cruise- } \\
\text { Core }\end{array}$ & $\begin{array}{l}\text { Coring } \\
\text { Depth } \\
\text { (mbsl) }\end{array}$ & Temperature Proxies Reported & Latitude & Longitude Age model development & Update Age Model & $\begin{array}{l}\text { Core } \\
\text { Length } \\
(\mathrm{m})\end{array}$ & $\begin{array}{l}\text { Sampling } \\
\text { Resolution } \\
(\mathrm{cm})\end{array}$ & $\begin{array}{l}\text { Sedimentation } \\
\text { rate }(\mathrm{cm} / \mathrm{kyr})\end{array}$ \\
\hline \multicolumn{9}{|c|}{ EASTERN PACIFIC } \\
\hline $\begin{array}{l}\text { EW0408- } \\
\quad 85 \mathrm{JC}\end{array}$ & 682 & Uk' $_{37}$ (Praetorius et al., 2015) using Prahl et al. (1998) & $59^{\circ} 33^{\prime} \mathrm{N}$ & $\begin{array}{l}\text { 144 } 9^{\prime} \text { W } \text { (Davies et al., 2011; Praetorius et al., } \\
\text { 2015) }\end{array}$ & OUD & 11.24 & $1-20$ & $100-200$ \\
\hline $\begin{array}{l}\text { EW0408- } \\
66 \mathrm{JC}\end{array}$ & 426 & Uk' 37 (Praetorius et al., 2016) using Prahl et al. (1998) & $58^{\circ} 52^{\prime} \mathrm{N}$ & $137^{\circ} 6^{\prime} \mathrm{W}$ (Praetorius et al., 2016) & OUD & 13.86 & $2-20$ & $200-2000$ \\
\hline $\begin{array}{l}\text { EW0408- } \\
26 \mathrm{TC} / \mathrm{JC}\end{array}$ & 1620 & Uk' $_{37}$ (Praetorius et al., 2016) using Prahl et al. (1998) & $56^{\circ} 57^{\prime} \mathrm{N}$ & $136^{\circ} 26^{`} \mathrm{~W}$ (Praetorius et al., 2016) & OUD & & $2-20$ & $100-2000$ \\
\hline $\begin{array}{l}\text { MD02- } \\
2489\end{array}$ & 3640 & Mg/Ca N. pachyderma (Gebhardt et al., 2008) & $54^{\circ} 39^{\prime} \mathrm{N}$ & $148^{\circ} 29^{\prime} W$ (Rae et al., 2014) & $\mathrm{R}$ & 29.8 & 2 & $15-50$ \\
\hline $\begin{array}{l}\text { SO202-27- } \\
\quad 6\end{array}$ & 2919 & Uk'$_{37}$ (Méheust et al., 2018) using Sikes et al. (1997) & $54^{\circ} 118^{\prime} \mathrm{N}$ & 149³6’W (Maier et al., 2018) & OUD & 2.92 & & \\
\hline JT96-09 & 920 & $\begin{array}{l}\text { Uk'}_{37} \text { (Kienast and McKay, 2001) using Müller et al. } \\
\text { (1998) }\end{array}$ & $48^{\circ} 54^{\prime} \mathrm{N}$ & $126^{\circ} 53^{\prime} \mathrm{W}$ (Kienast and McKay, 2001) & $\mathrm{R}$ & 4.14 & 5 & $5-169$ \\
\hline $\begin{array}{l}\text { W8709A- } \\
\text { 53GC }\end{array}$ & 2408 & Uk' $_{37}$ (Doose et al., 1997) using Prahl et al. (1998) & $42^{\circ} 45^{\prime} \mathrm{N}$ & $126^{\circ} 15^{\prime} \mathrm{W}$ (Ortiz et al., 1997) & $\mathrm{R}$ & 2.58 & & \\
\hline $\begin{array}{l}\text { W8709A- } \\
\text { 13PC }\end{array}$ & 2717 & Uk'37 (Doose et al., 1997) using Prahl et al. (1998) & $42^{\circ} 1^{\prime} \mathrm{N}$ & $125^{\circ} 45^{\prime} \mathrm{W}$ (Ortiz et al., 1997) & $\mathrm{R}$ & 8.72 & 10 & $21-24$ \\
\hline $\begin{array}{l}\text { ODP } \\
1019 C\end{array}$ & 988 & $\begin{array}{l}\mathrm{Uk}^{\prime}{ }_{37}, \delta^{18} \mathrm{O} \text { (Mix et al., 1999; Pisias et al., 2001; Barron, } \\
\text { 2003) using Prahl et al. (1998) }\end{array}$ & $41^{\circ} 40^{\prime} \mathrm{N}$ & $124^{\circ} 55^{\prime} \mathrm{W}$ (Lopes and Mix, 2009) & OID & 214 & 61 & 61 \\
\hline $\begin{array}{l}\text { W8809A- } \\
\text { 57GC }\end{array}$ & 3330 & $\mathrm{Uk}_{37}$ (Doose et al., 1997) using Prahl et al. (1998) & $41^{\circ} 34^{\prime} \mathrm{N}$ & $130^{\circ} 37^{\prime} W$ (Ortiz et al., 1997) & $\mathrm{R}$ & 2.52 & & \\
\hline F2-92-P3 & 799 & Uk $_{37}$ (Doose et al., 1997) using Prahl et al. (1998) & $35^{\circ} 37^{\prime} \mathrm{N}$ & $121^{\circ} 36^{\prime} \mathrm{W}$ (Zheng et al., 2000) & $\mathrm{R}$ & 5.78 & 10 & 12 \\
\hline F2-92-P34 & 610 & Uk' $_{37}$ (Doose et al., 1997) using Prahl et al. (1998) & $35^{\circ} 25^{\prime} \mathrm{N}$ & $121^{\circ} 24^{\prime} \mathrm{W}$ (Gardner et al., 1997) & $\mathrm{R}$ & 5.7 & 10 & 13 \\
\hline \multicolumn{9}{|c|}{ WESTERN PACIFIC } \\
\hline $\begin{array}{l}\text { SO201-2- } \\
\quad 12 \mathrm{KL}\end{array}$ & 2145 & Uk' $_{37}$ (Max et al., 2012) using Sikes et al. (1997) & $53^{\circ} 59^{\prime} \mathrm{N}$ & $162^{\circ} 22^{\prime} \mathrm{E} \quad$ (Max et al., 2012) & $\mathrm{R}$ & 9.05 & & \\
\hline $\begin{array}{l}\text { MD01- } \\
2416\end{array}$ & 2317 & $\begin{array}{l}\mathrm{Mg} / \mathrm{Ca} \text { N. pachyderma, } \delta^{18} \mathrm{O} \text { (Gebhardt et al., 2008; } \\
\text { Sarnthein et al., 2004) }\end{array}$ & $51^{\circ} 16^{\prime} \mathrm{N}$ & $167^{\circ} 44^{\prime} \mathrm{E}$ (Gray et al., 2018) & $\mathrm{R}$ & 44.75 & $1-2$ & $10-36$ \\
\hline $\begin{array}{l}\text { SO202-07- } \\
\quad 6\end{array}$ & 2340 & Uk' 37 (Méheust et al., 2018) using Sikes et al. (1997) & $51^{\circ} 16^{\prime} \mathrm{N}$ & 167²'W (Serno et al., 2015) & $\mathrm{R}$ & 4.77 & & \\
\hline 4-GC37 & 3300 & $\delta^{18} \mathrm{O}$ (Keigwin, 1998) & $50^{\circ} 25^{\prime} \mathrm{N}$ & $\begin{array}{l}167^{\circ} 44^{\prime} \mathrm{E} \text { (Cook and Keigwin, 2015; Keigwin, } \\
\text { 1998) }\end{array}$ & $\mathrm{R}$ & 1.5 & & $2.9-7.7$ \\
\hline $\begin{array}{r}\text { KT90-9- } \\
\text { ST-21 }\end{array}$ & 1083 & $\delta^{18} \mathrm{O}$ (Oba and Murayama, 2004) & $42^{\circ} 27^{\prime} \mathrm{N}$ & $144^{\circ} 19^{\prime} \mathrm{E}$ (Ohkushi et al., 2000) & $\mathrm{R}$ & 4.47 & 20 & 21.6 \\
\hline $\begin{array}{l}\mathrm{GH} 02- \\
1030\end{array}$ & 1212 & $\begin{array}{l}\text { Uk'}_{37} \text { (Ikehara et al, 2009; Harada et al., 2012) using } \\
\text { Prahl et al. (1998) }\end{array}$ & $42^{\circ} 14^{\prime} \mathrm{N}$ & 144¹3’E (Ikehara et al., 2006) & $\mathrm{R}$ & 7 & & $31-40$ \\
\hline $\begin{array}{l}\text { KR02-15- } \\
\quad \text { PC6 }\end{array}$ & 2215 & $\begin{array}{l}\text { Uk' }_{37} \text { (Harada et al., 2012; Minoshima et al., 2007a) } \\
\text { using Prahl et al. (1998) }\end{array}$ & $40^{\circ} 24^{\prime} \mathrm{N}$ & 143³0’E (Minoshima et al., 2007b) & $\mathrm{R}$ & 7.443 & & \\
\hline CMC18 & 5389 & Uk $_{37}^{\prime}$ (Yamamoto et al., 2007) using Prahl et al. (1998) & $39^{\circ} 14^{\prime} \mathrm{N}$ & $144^{\circ} 13^{\prime} \mathrm{E}$ (Yamamoto et al., 2007) & $\mathrm{R}$ & 0.3 & & \\
\hline $\begin{array}{l}\text { MD01- } \\
2420\end{array}$ & 2101 & Mg/Ca G. bulloides, $\delta 180$ (Sagawa et al., 2006) & $36^{\circ} 04^{\prime} \mathrm{N}$ & $141^{\circ} 49^{\prime} \mathrm{E}$ (Okazaki et al., 2012) & $\mathrm{R}$ & 8.99 & & 30 \\
\hline $\begin{array}{l}\text { MD01- } \\
2421\end{array}$ & 2224 & $\begin{array}{l}\text { Uk' }_{37} \text { (Yamamoto et al., 2004; Isono et al., 2009) using } \\
\text { Prahl et al. (1998) }\end{array}$ & $36^{\circ} 1^{\prime} \mathrm{N}$ & $141^{\circ} 46^{\prime} \mathrm{E}$ (Oba et al., 2006; Isono et al., 2009) & $\begin{array}{l}\mathrm{R} \text { (Yamamoto et al., 2004); OID } \\
\text { (Isono et al., 2009) }\end{array}$ & 45.82 & 15 & \\
\hline \multicolumn{9}{|c|}{ The } \\
\hline $\begin{array}{l}\text { HLY02- } \\
\text { 02-3JPC }\end{array}$ & 1132 & $\delta^{18} \mathrm{O}$ (Cook et al., 2005) & $60^{\circ} 8^{\prime} \mathrm{N}$ & 179²7’E (Cook et al., 2005) & $\mathrm{R}$ & & 12 & \\
\hline $\begin{array}{l}\text { SO202-18- } \\
\quad 6\end{array}$ & 1105 & Uk'$_{37}$ (Méheust et al., 2018) using Sikes et al. (1997) & $60^{\circ} 8^{\prime} \mathrm{N}$ & $179^{\circ} 26^{\prime} \mathrm{W}$ (Kuehn et al., 2014) & OUD & 7.21 & & \\
\hline $\begin{array}{l}\text { SO201-2- } \\
\quad 114 \mathrm{KL}\end{array}$ & 1376 & Uk' $_{37}^{\prime}$ (Max et al., 2012) using Sikes et al. (1997) & $59^{\circ} 14^{\prime} \mathrm{N}$ & 16659’E (Max et al., 2012) & $\mathrm{R}$ & 2 & & \\
\hline SO201-2- & 968 & Uk' $_{37}$ (Max et al., 2012) using Sikes et al. (1997) & $57^{\circ} 30^{\prime} \mathrm{N}$ & $170^{\circ} 25^{\prime} \mathrm{E} \quad$ (Max et al., 2012) & $\mathrm{R}$ & 18.13 & 5 & \\
\hline
\end{tabular}




\begin{tabular}{|c|c|c|c|c|c|c|c|c|c|}
\hline $\begin{array}{l}\text { SO201-2- } \\
\quad 77 \mathrm{KL}\end{array}$ & 2135 & Uk'$_{37}$ (Max et al., 2012) using Sikes et al. (1997) & $56^{\circ} 20^{\prime} \mathrm{N}$ & $170^{\circ} 42^{\prime} \mathrm{E}$ & (Max et al., 2012) & $\mathrm{R}$ & 11.78 & 5 & $11-16$ \\
\hline $\begin{array}{c}\text { HLY02- } \\
02- \\
51 \mathrm{JPC}\end{array}$ & 1467 & $\begin{array}{l}\delta^{18} \mathrm{Op} \text { (Caissie et al., 2010; Cook et al., 2005) using Prahl } \\
\text { et al. (1998) }\end{array}$ & $54^{\circ} 33^{\prime} \mathrm{N}$ & $168^{\circ} 40^{\prime} \mathrm{E}$ & (Cook et al., 2005; Caissie et al., 2010) & $\mathrm{R}$ & 19.56 & 12 & $15-20$ \\
\hline $\begin{array}{c}\text { HLY02- } \\
02- \\
17 J P C\end{array}$ & 2209 & $\delta^{18} \mathrm{O}$ (Brunelle et al., 2007; Cook et al., 2005) & $53^{\circ} 56^{\prime} \mathrm{N}$ & $178^{\circ} 42^{\prime} \mathrm{E}$ & (Cook et al., 2005; Brunelle et al., 2007) & $R$ & 3.17 & 12 & $12-15$ \\
\hline $\begin{array}{r}\text { 91-AV-19/ } \\
4-G C 11\end{array}$ & 3060 & $\begin{array}{l}\delta^{18} \text { Op (Gorbarenko et al., 2005; Gorbarenko et al., 2010; } \\
\text { Gorbarenko, 1996) }\end{array}$ & $53^{\circ} 31^{\prime} \mathrm{N}$ & $178^{\circ} 51^{\prime} \mathrm{E}$ & $\begin{array}{l}\text { (Gorbarenko et al., 2005; Gorbarenko } \\
\text { et al., 2010; Keigwin, 1998) }\end{array}$ & $\mathrm{R}$ & 6.5 & 5 & $1.9-12.25$ \\
\hline $\mathrm{U} 1340$ & 1294 & $\begin{array}{l}\text { Uk }_{37}, \delta^{18} \mathrm{O} \text { (Schlung et al., 2013) using Müller et al. } \\
(1998)\end{array}$ & $53^{\circ} 24^{\prime} \mathrm{N}$ & $179^{\circ} 31^{\prime} \mathrm{W}$ & (Schlung et al., 2013) & $\mathrm{R}$ & 604 & & $3-32$ \\
\hline \multicolumn{10}{|c|}{ SEA OF OKHOTSK } \\
\hline XP07-C9 & 1431 & Uk' $_{37}$ (Harada et al 2012) using Prahl et al. (1998) & $52^{\circ} 15^{\prime} \mathrm{N}$ & $146^{\circ} 0^{\prime} \mathrm{E}$ & (Harada et al 2012) & OID & 6.8 & & \\
\hline LV28-42-4 & 1041 & $\delta^{18} \mathrm{O}$ (Nürnberg et al., 2011) & $51^{\circ} 43^{\prime} \mathrm{N}$ & $150^{\circ} 59^{\prime} \mathrm{E}$ & (Nürnberg et al., 2004) & $\mathrm{R}$ & 10.84 & 5.1 & $2-22$ \\
\hline LV28-41-4 & 1082 & $\delta^{18} \mathrm{O}$ (Nürnberg et al., 2011) & $51^{\circ} 41^{\prime}$ & $149^{\circ} 04^{\prime} \mathrm{E}$ & (Nürnberg et al., 2011) & OID & 9.81 & & $1-6$ \\
\hline LV28-40-4 & 1370 & $\delta^{18} \mathrm{O}$ (Nürnberg et al., 2011) & $51^{\circ} 20^{\prime} \mathrm{N}$ & $147^{\circ} 12^{\prime} \mathrm{E}$ & (Nürnberg et al., 2011) & OID & & & $\sim 4-23$ \\
\hline $\begin{array}{l}\text { MR06-04- } \\
\text { PC07R }\end{array}$ & 1256 & Uk $_{37}^{\prime}$ (Harada et al., 2012) using Prahl et al. (1998) & $51^{\circ} 17^{\prime} \mathrm{N}$ & $149^{\circ} 13^{\prime} \mathrm{E}$ & (Gorbarenko et al., 2012) & OUD & 17.22 & $1-2$ & \\
\hline 936 & 1305 & $\delta^{18} \mathrm{O}$ (Gorbarenko et al., 2004) & $51^{\circ} 01^{\prime} \mathrm{N}$ & $148^{\circ} 19^{\prime} \mathrm{E}$ & (Gorbarenko et al., 2014) & $\mathrm{R}$ & 7 & 3-5 & 16 \\
\hline XP98 PC-2 & 1258 & $\begin{array}{l}\text { Uk' }_{37} \text { (Harada et al., 2012; Okazaki et al., 2006; Seki } \\
\text { et al., 2004) using Prahl et al. (1998) }\end{array}$ & $50^{\circ} 24^{\prime} \mathrm{N}$ & $148^{\circ} 19^{\prime} \mathrm{E}$ & (Seki et al., 2004) & OID & 10.23 & 2.4 & 11 \\
\hline V34-98 & 1175 & $\delta^{18} \mathrm{O}$ (Gorbarenko et al., 2002) & $50^{\circ} 07^{\prime} \mathrm{N}$ & $153^{\circ} 12^{\prime} \mathrm{E}$ & (Gorbarenko et al., 2002) & $\mathrm{R}$ & 33 & & 17 \\
\hline XP98 PC-4 & 664 & $\begin{array}{l}\text { Uk' }_{37} \text { (Harada et al., 2012; Seki et al., 2004) using Prahl } \\
\text { et al. (1998) }\end{array}$ & $49^{\circ} 29^{\prime} \mathrm{N}$ & $146^{\circ} 08^{\prime} \mathrm{E}$ & (Seki et al., 2004) & OID & 11.28 & 2.4 & 13 \\
\hline $\begin{array}{l}\text { MRO0K3- } \\
\text { PC4 }\end{array}$ & 1821 & Uk'$_{37}$ (Harada et al 2012) using Prahl et al. (1998) & $49^{\circ} 22^{\prime} \mathrm{N}$ & $153^{\circ} 01^{\prime} \mathrm{E}$ & (Harada et al., 2004) & $\mathrm{R}$ & 20.6 & $1-2$ & $0.7-24$ \\
\hline V34-90 & 1590 & $\delta^{18} \mathrm{O}$ (Gorbarenko et al., 2002) & $48^{\circ} 50^{\prime} \mathrm{N}$ & $150^{\circ} 28^{\prime} \mathrm{E}$ & (Gorbarenko et al., 2002) & $\mathrm{R}$ & 3.4 & 3.5 & 15 \\
\hline GGC-15 & 1980 & $\mathrm{Uk}_{37}^{\prime}, \delta^{18} \mathrm{O}$ (Ternois et al., 2000) using Prahl et al. (1998) & $48^{\circ} 10^{\prime} \mathrm{N}$ & $151^{\circ} 20^{\prime} \mathrm{E}$ & (Keigwin, 1998) & $\mathrm{R}$ & 3.21 & $5-10$ & $4-23$ \\
\hline $\begin{array}{l}\text { MR06-04- } \\
\text { PC04 }\end{array}$ & 1217 & Uk' $_{37}$ (Harada et al 2012) using Prahl et al. (1998) & $44^{\circ} 32^{\prime} \mathrm{N}$ & $145^{\circ} 0^{\prime} \mathrm{E}$ & (Okazaki et al., 2014) & $\mathrm{R}$ & 18.292 & & \\
\hline $\begin{array}{l}\text { MD01- } \\
2412\end{array}$ & 1225 & $\begin{array}{l}\text { Uk'}_{37} \text { (Harada et al., 2006; Harada et al., 2008; Harada } \\
\text { et al., 2012) using Prahl et al. (1998) }\end{array}$ & $44^{\circ} 31^{\prime} \mathrm{N}$ & $145^{\circ} 00^{\prime} \mathrm{E}$ & (Okazaki et al., 2005) & $\mathrm{R}$ & 52.69 & 2.4 & $41.2-115.5$ \\
\hline
\end{tabular}




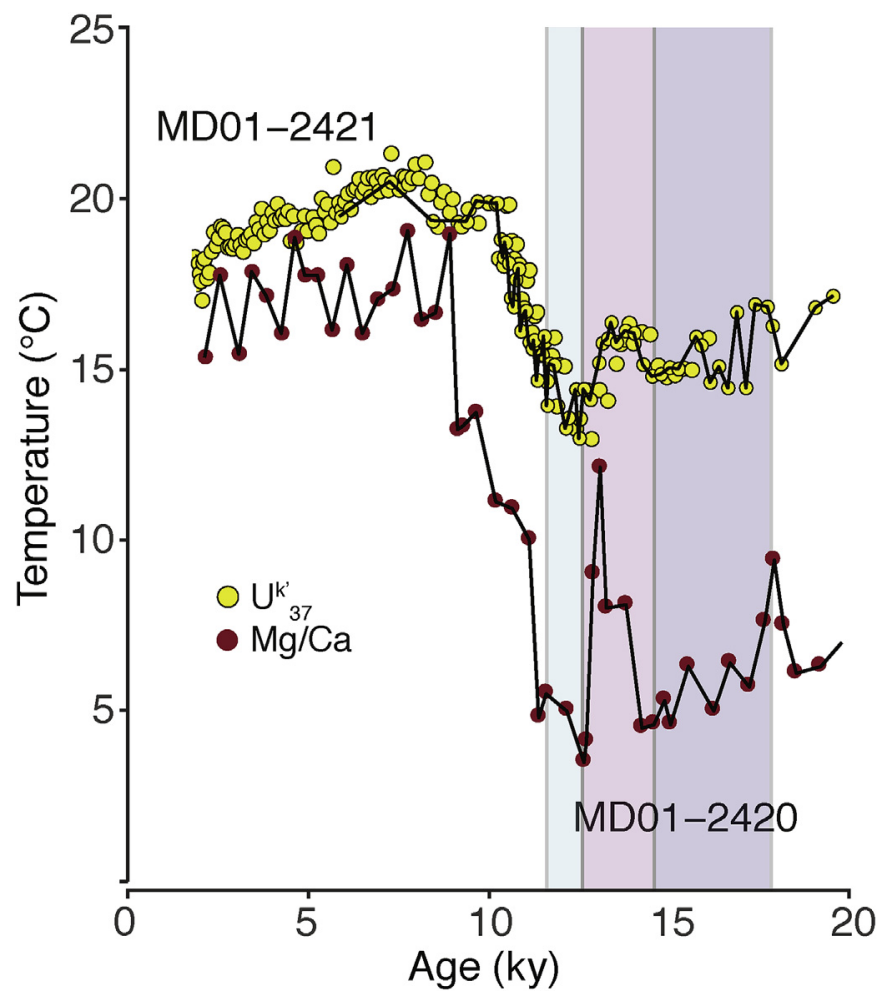

Fig. 2. Comparison of $\mathrm{U}^{\mathrm{k}^{\prime}}{ }_{37}$ (yellow) and $\mathrm{Mg} / \mathrm{Ca}$ (red) SST records from MD01-2421 and MD01-2420 respectively in the Western North Pacific. Purple shading denotes the Heinrich Stadial 1 Interval, pink the Bølling-Allerød, and blue the Younger Dryas from Greenland records. Both available $\mathrm{U}^{\mathrm{k}^{\prime}}{ }_{37}$ records for MD01-2420 have been included, although only the record reported by Yamamoto et al. (2004), with updated age model, has been connected with lines. (For interpretation of the references to color in this figure legend, the reader is referred to the Web version of this article.)

\section{Results and discussion}

\subsection{Reconciling sea surface temperature proxies}

We attempt to reconcile temperature proxies to produce a comprehensive record of North Pacific summer/fall SSTs from $\delta^{18} \mathrm{O}_{\text {temp }}, \mathrm{Mg} / \mathrm{Ca}$, and $\mathrm{U}^{\mathrm{k}^{\prime}} 37$ for the last 20ka. This approach allows for the utilization of multiple record types, and the identification of sites and circumstances under which some records are preferable for SST reconstruction.

In the Western Pacific and Sea of Okhotsk, we find that $\mathrm{U}^{\mathrm{k}^{\prime}} 37$ temperatures are less reliable under cooler $\left(<10{ }^{\circ} \mathrm{C}\right)$ conditions (Figs. 2, 4 and 7). Additionally, $\delta^{18} \mathrm{O}_{\text {temp }}$ records may be influenced by local salinity during periods of unconstrained and rapid changes in $\delta^{18} \mathrm{O}_{\text {seawater. }}$ In the Sea of Okhotsk and along the Japan margin, $\mathrm{U}^{\mathrm{k}^{\prime}}{ }_{37}$ records produce warmer temperatures than $\delta^{18} \mathrm{O}_{\text {temp }}$ or $\mathrm{Mg} / \mathrm{Ca}$ records regardless of the calibration used, during the Last Glacial Maximum (>18 ka) and Heinrich Stadial 1 ( 17.9-14.7 ka) (Fig. 2). Warm Last Glacial Maximum temperatures, interpreted from $\mathrm{U}^{\mathrm{k}^{\prime}}{ }_{37}$, have previously been attributed to basin isolation in the Sea of Japan and the Sea of Okhotsk (Ishiwatari et al., 2001; Seki et al., 2004). However, comparisons between neighboring sites suggest that in many instances, warm deglacial $\mathrm{U}^{\mathrm{k}^{\prime}} 37$ temperatures are more likely to be proxy-specific artifacts. For example, adjacent $\mathrm{Mg} / \mathrm{Ca}$ (MD01-2420) and $\mathrm{U}^{\mathrm{k}^{\prime}}{ }_{37}$ (MD01-2421) records give comparable temperatures through the Holocene $\left(15-23{ }^{\circ} \mathrm{C}\right)$, though $\mathrm{Mg} / \mathrm{Ca}$ from the shells of $G$. bulloides remains somewhat cooler than $U^{k^{\prime}}{ }_{37}$ temperatures (Fig. 2). However, during deglaciation the $\mathrm{Mg} / \mathrm{Ca}$ record indicates temperatures of $\sim 5-10^{\circ} \mathrm{C}$ while the $\mathrm{U}^{\mathrm{k}^{\prime}} 37$ index indicates SSTs of $\sim 15^{\circ} \mathrm{C}$ (Fig. 2). This could be due to a breakdown of the $\mathrm{U}^{\mathrm{k}^{\prime}}{ }_{37}$ temperature relationship at low temperatures (i.e. Sikes et al., 1997; Rosell-Mele, 1998), a more limited coccolithophore growth season during cold intervals (Seki et al., 2009; Harada et al., 2012), changes in nutrient availability (Minoshima et al., 2007a), or analytical uncertainties due to small sample sizes and low alkenone abundance. Interpretations of Last Glacial Maximum $\mathrm{U}^{\mathrm{k}^{\prime}} 37$ records as artificially warm in the Western Pacific and the Sea of Okhotsk cannot be directly applied to the Bering Sea due to a lack of overlap between proxy types in the region (Fig. 3).

Foraminiferal $\delta^{18} \mathrm{O}$ records bear the dual signal of temperature and $\delta^{18} \mathrm{O}_{\text {seawater, therefore incorrect assumptions made about }}$ $\delta^{18} \mathrm{O}_{\text {seawater }}$ will skew temperature reconstructions. We have attempted to deconvolve competing signals of temperature and

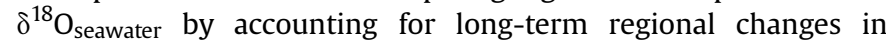
$\delta^{18} \mathrm{O}_{\text {seawater }}$ (see Supplemental text). Nevertheless, temporal and spatial differences between sites make this an imperfect approach. The use of regional $\delta^{18} \mathrm{O}_{\text {seawater }}$ records to account for local changes may be especially important in the Sea of Okhotsk and Bering Sea, due to the likelihood of fresh intervals during the deglaciation caused by increased riverine runoff (Gorbarenko et al., 2004; Seki et al., 2009; Riethdorf et al., 2013; Lembke-Jene et al., 2017). Additional variability in the extent of sea ice or the amount or

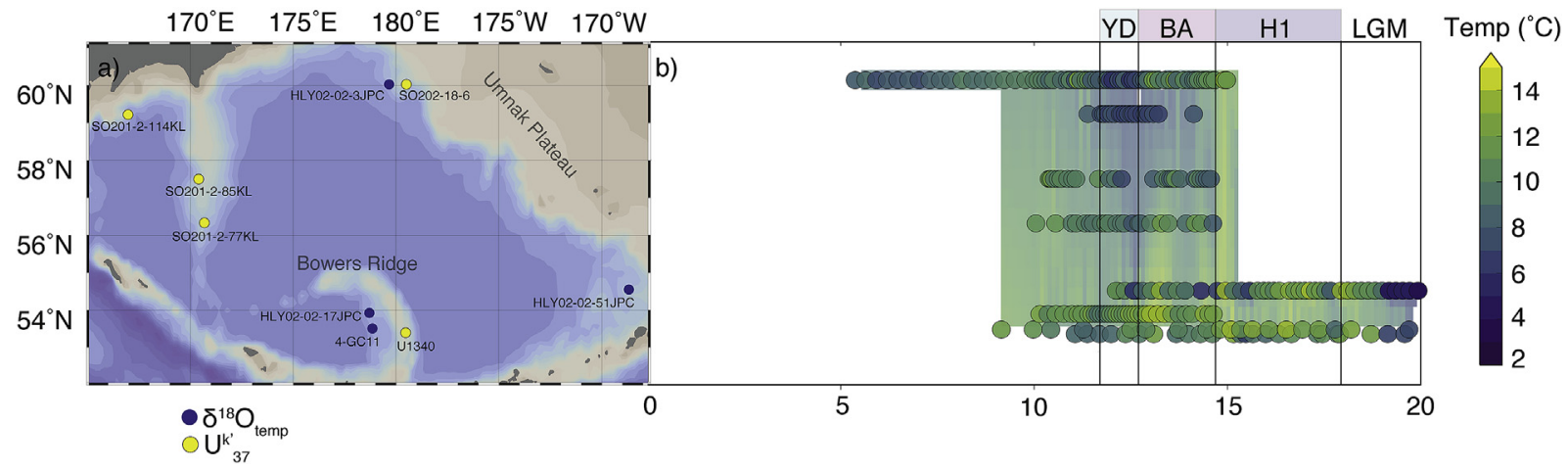

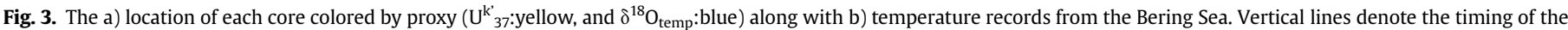

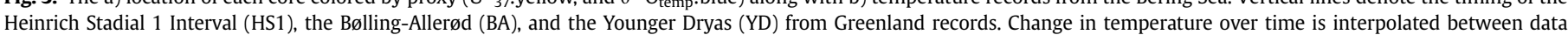
points, and latitudinally between cores. (For interpretation of the references to color in this figure legend, the reader is referred to the Web version of this article.) 


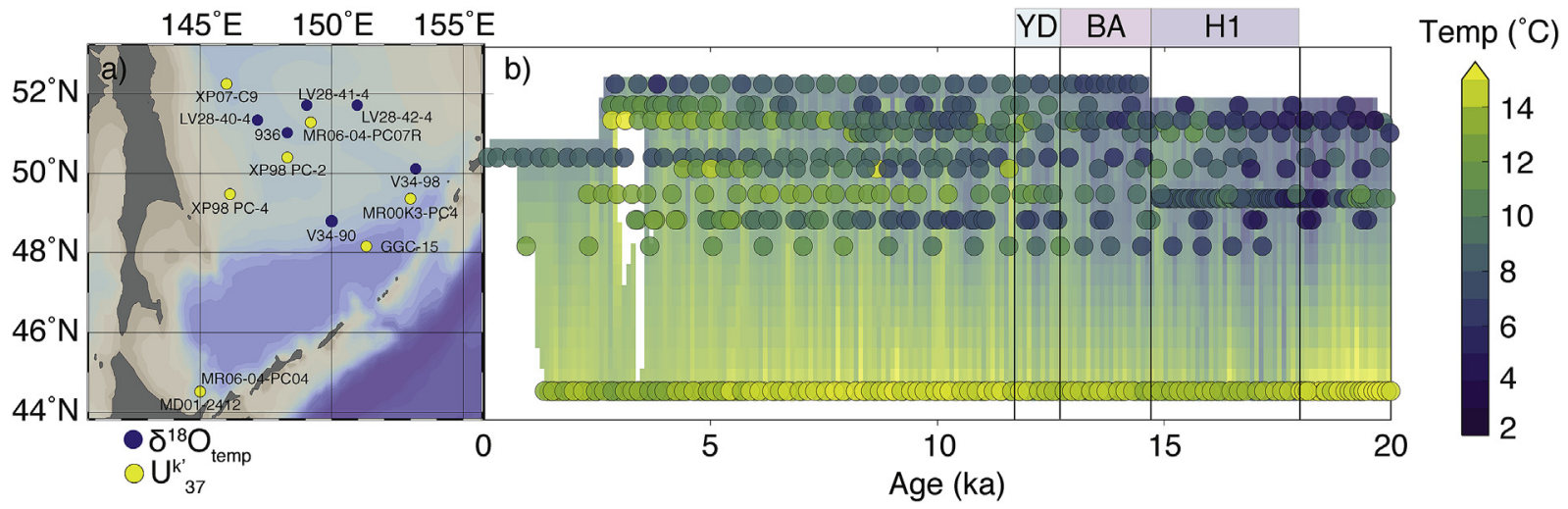

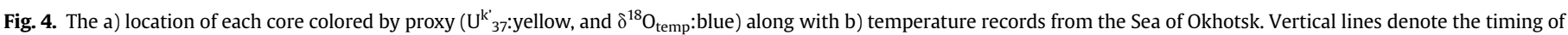

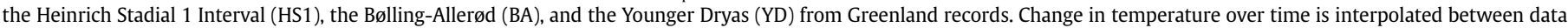
points, and latitudinally between cores. (For interpretation of the references to color in this figure legend, the reader is referred to the Web version of this article.)

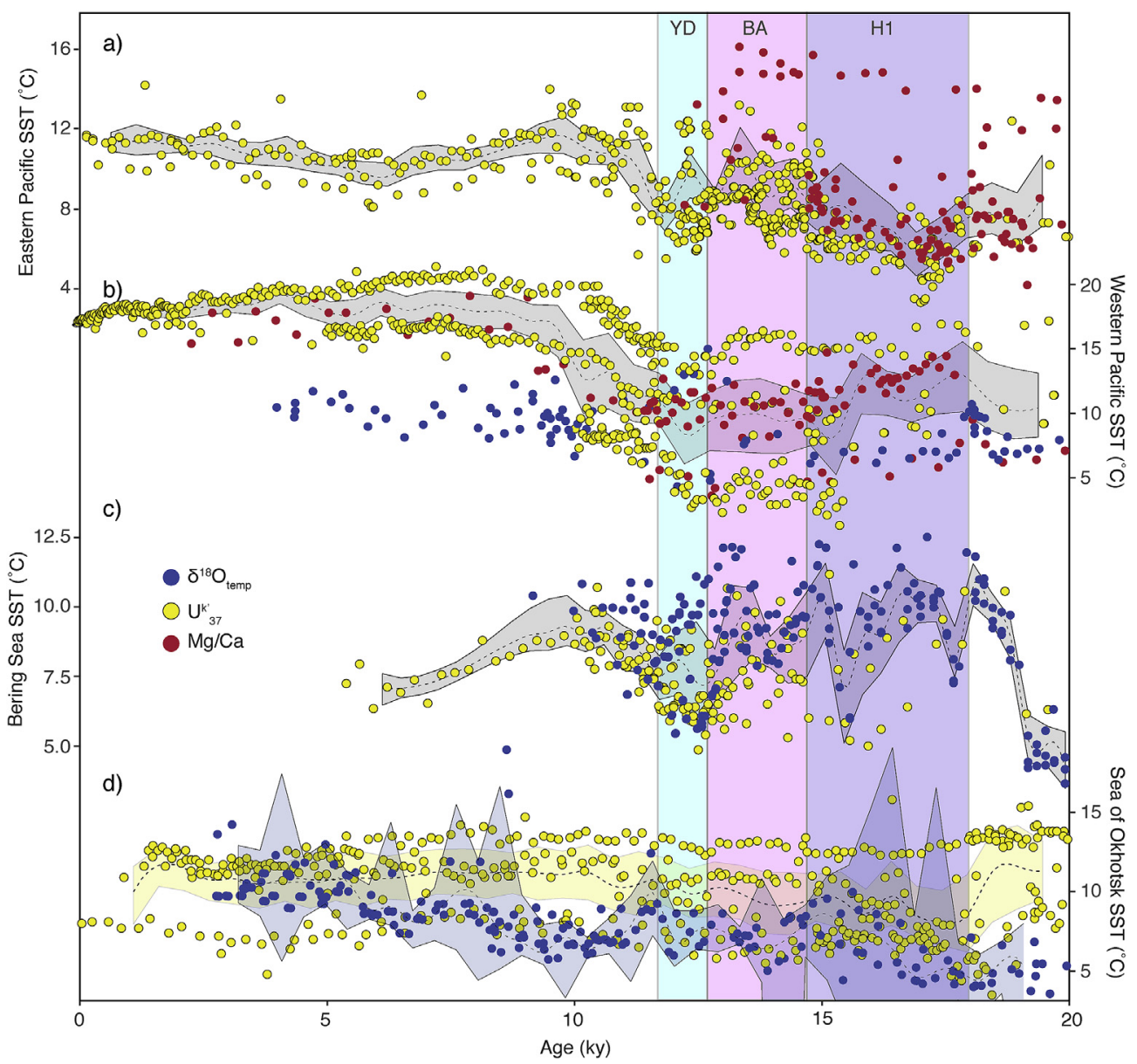

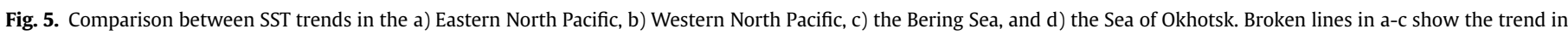

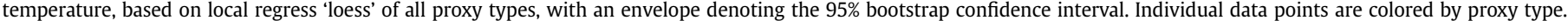

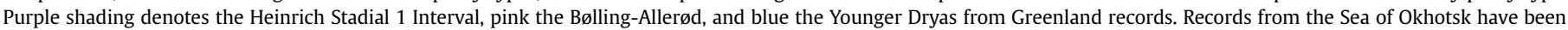

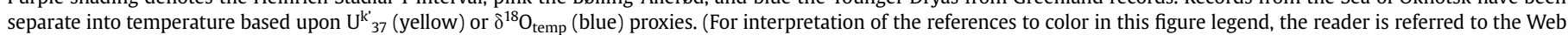
version of this article.)

source of runoff could lead to spatial variability in $\delta^{18} \mathrm{O}_{\text {seawater }}$ on time-scales shorter than captured in paired records ( $\sim$ centennial). Therefore, the $\delta^{18} \mathrm{O}_{\text {temp }}$ records presented here may still be influenced somewhat by freshwater inputs, especially for cores located farther from $\delta^{18} \mathrm{O}_{\text {seawater }}$ tie-sites or during periods of rapid change in freshwater delivery. The generation and publication of additional paired $\delta^{18} \mathrm{O}_{\text {seawater }}$ records will provide a needed test of the degree of variability left unaccounted for by our approach, and could facilitate the generation of SST records from other $\delta^{18} \mathrm{O}$ records.

Foraminiferal $\mathrm{Mg} / \mathrm{Ca}$ records present their own caveats, 
including the need for species-specific calibrations (Nürnberg et al., 1996; Lea et al., 1999; Mashiotta et al., 1999; Regenberg et al., 2009), and the potential for influences of salinity (e.g., Lea et al., 1999; Hönisch et al., 2013), carbonate chemistry (e.g., Lea et al., 1999; Russell et al., 2004), and dissolution (e.g., Dekens et al., 2000; Regenberg et al., 2014).

\subsection{Subpolar marginal seas}

\subsubsection{The Bering Sea}

Prior to $16 \mathrm{ka}$, regional SST records are only available for sites south of $55^{\circ} \mathrm{N}$, two of which rely on $\delta^{18} \mathrm{O}_{\text {temp }}$ (HLY02-02-51JPC and 4-GC-11) (Fig. 3). These records indicate warming initiating in the Last Glacial Maximum through Heinrich Stadial 1 (at $\sim 19$ and $\sim 17$ ka) (Fig. 3). Alkenone-reconstructed site U1340 shows a similar overall trend, although lower resolution at this site makes specific warming events difficult to interpret (Fig. 3). Regardless of proxy approach, Heinrich Stadial 1 in the southern Bering Sea appears relatively warm, with temperatures comparable to the Holocene, and higher than during the Last Glacial Maximum (Figs. 3 and 5, Supplemental Fig. 3). A relatively warm Heinrich Stadial 1 in the southern Bering Sea also coincides with a shift from perennial to seasonal sea ice on the Umnak Plateau (Caissie et al., 2010).

Warming during the Bølling-Allerød is characteristic of many of the records in the Bering Sea (Fig. 3). Cores from the Umnak Plateau (HYL02-02-51JPC) and Bowers Ridge (U1340) appear to begin warming centuries prior ( 15.2 ka) to the Bølling-Allerød (Fig. 3). This warm pulse has previously been noted in several cores and proposed to be either a true signal (Seki et al., 2002; Kiefer and Kienast, 2005; Sarnthein et al., 2006) or an artifact of reservoir age uncertainties in carbon dating (Schlung et al., 2013) and therefore more rightfully associated with the onset of the BøllingAllerød. Uncertainty in age models, and the binning of data at 100 year intervals, does not allow us to directly address questions of centennial scale timing. However, the prevalence of this feature across cores can be taken as suggestive that SST warming likely began prior to the Bølling-Allerød in the Bering Sea.

Deglacial SST trends following the onset of the Bølling-Allerød are inconsistent across Bering Sea cores and do not display a strong latitudinal gradient in SST (Fig. 3), with western sites generally cooler than those along Bowers Ridge or the Umnak Plateau. The complexity of the deglaciation may be derived from the physical reorganization of the basin associated with the reopening of the Bering Strait, inundation of the shallow shelf, loss of sea ice, and a redirection of Alaskan rivers into the Bering Sea (Sancetta, 1983; Caissie et al., 2010; Pelto et al., 2018). During the deglaciation, several records from across the Bering Sea (HYL02-02-17JPC, SO201-2-85 KL and HYL02-02-51JPC) indicate a cool early BøllingAllerød, followed by warming. A cool interval is present at most sites at $12.9-11.7 \mathrm{ka}$, associated with the Younger Dryas, followed by a gradual warming at the start of the Holocene (Figs. 3 and 5). Sea surface temperatures during the Younger Dryas are highly variable at some sites, especially in the northwest (i.e. SO201-2$77 \mathrm{KL}$ and SO201-2-85 KL), but most available Bering Sea records are too low resolution to capture such variability (Fig. 3; Supplementary Fig. 3).

\subsubsection{The Sea of Okhotsk}

The timing of temperature oscillations in the Sea of Okhotsk is generally in keeping with that observed across the rest of the high latitude North Pacific. However, the direction of SST change in the Sea of Okhotsk often differs from the rest of the North Pacific and is depend upon proxy source (Fig. 4; Fig. 5; Supplemental Fig. 4). $\mathrm{U}^{\mathrm{k}^{\prime}}{ }_{37}$ records from the Last Glacial Maximum appear to have a warm bias not reflected in adjacent $\delta^{18} \mathrm{O}$, however this disparity between proxy records also reappears at points through the deglaciation and into the Holocene. At odds with $\mathrm{U}^{\mathrm{k}^{\prime}}{ }_{37}$ records, $\delta^{18} \mathrm{O}_{\text {temp }}$ records show warming from a cool Last Glacial Maximum beginning during Heinrich Stadial 1 (Fig. 5). Most $\delta^{18} \mathrm{O}_{\text {temp }}$ records also indicate a cool Bølling-Allerød, followed by a relatively warm Younger Dryas, and gradual warming through the mid-Holocene (Fig. 4; Fig. 5). In contrast, most $\mathrm{U}^{\mathrm{k}^{\prime}} 37$ records show a warm Last Glacial Maximum, cooling initiating just prior to the onset of the Bølling-Allerød, and a comparatively warm Younger Dryas. $\mathrm{U}^{\mathrm{k}^{\prime}}{ }_{37}$ records all show a more gradual warming through the deglaciation and no abrupt transition at the onset of the Holocene (Fig. 4; Fig. 5).

The apparent mismatches between proxy records could be attributed to several possible causes. The first is the suite of previously discussed biases associated with $\mathrm{U}^{\mathrm{k}^{\prime}}{ }_{37}$, which could cause cold periods to appear unexpectedly warmer. Supporting this is the observation that relatively high $\mathrm{U}^{\mathrm{k}^{\prime}} 37$ temperatures frequently occur when $\delta^{18} \mathrm{O}$ temperatures indicate SSTs lower than $\sim 10^{\circ}$ (Fig. 5). This, however, cannot explain the north-south gradient in $\mathrm{U}^{\mathrm{k}^{\prime}} 37$ temperature, maintained throughout the deglaciation and comparable with modern oceanography in the region (Locarnini et al., 2013, Fig. 4). If this source of bias were the sole cause of the proxy mismatch in the Sea of Okhotsk, warmer $\mathrm{U}^{\mathrm{k}^{\prime}}{ }_{37}$ SSTs would be expected at higher latitudes during the coolest intervals, or all regions should appear to warm; neither scenario is supported by the available records (Fig. 4). One additional possibility is that the distribution of records influenced the difference between proxies. For example, the two highest resolution sites for which $\mathrm{U}^{\mathrm{k}^{\prime}}{ }_{37}$ is available (MD01-2412 \& MR06-04-PC04) are both located in the far south of the Sea of Okhotsk, raising the possibility that equivalent glacial and Holocene temperatures are real but an artifact of local conditions at these sites. This possibility cannot be entirely discounted, but we note that $\mathrm{U}^{\mathrm{k}^{\prime}} 37$ sites XP98 PC-4 and XP98 PC-2 also record comparable temperatures during the end of the Last Glacial Maximum and early Holocene, if at much lower resolution.

Another possibility regarding the SST proxy mismatch relates to the assumption that foraminiferal $\delta^{18} \mathrm{O}$ can be related directly to SST. This may not be the case in the Sea of Okhotsk, because $N$. pachyderma, the species used in all Sea of Okhotsk $\delta^{18} \mathrm{O}$ records included here, calcifies at 30-40 m depth in the region (Alderman, 1996). That may place them in the dicothermal layer ( 30-130 m summer depth), an environment not readily comparable to surface waters (Max et al., 2012). The strength of this idea is attenuated by the presence of an additional $\delta^{18} \mathrm{O}$ record from the shallowerdwelling foraminifer $G$. bulloides, not available for this synthesis, that resembles the deglacial trends of $N$. pachyderma $\delta^{18} \mathrm{O}_{\text {temp }}$ rather than $U^{\mathrm{k}^{\prime}}{ }_{37}$ records (Gorbarenko et al., 2010). Moreover, an interpretation of $\delta^{18} \mathrm{O}_{\text {temp }}$ as a record of dicothermal waters throughout the past $20 \mathrm{ka}$ would imply an unrealistically warm $\left(\sim 12{ }^{\circ} \mathrm{C}\right)$ dicothermal layer in the recent Holocene, in contrast to measured modern temperatures of $<6{ }^{\circ} \mathrm{C}$ (Locarnini et al., 2013) (Fig. 4; Fig. 5). While too little is known about the deglacial depth habitats of these species to rule out a depth migration during the deglaciation, an alternative explanation may be required.

Glacial ice melt and surface freshening in the Sea of Okhotsk may be key to understanding the contradictory proxy signals. Strong Last Glacial Maximum stratification has previously been described in the Sea of Okhotsk (Seki et al., 2004), with surface freshening suggested as a source for changing planktic foraminiferal $\delta^{18} \mathrm{O}$ (Gorbarenko et al., 2004; Riethdorf et al., 2013), and fluvial runoff and melt water as a potential cause for the pre-Holocene cooling seen in alkenone records from GGC-15 (Ternois et al. 2000). A runoff signal would include both freshening (apparent warming) and cooling in summer/fall SSTs, both of which are recorded in foraminiferal $\delta^{18} \mathrm{O}$, and potentially not well corrected 


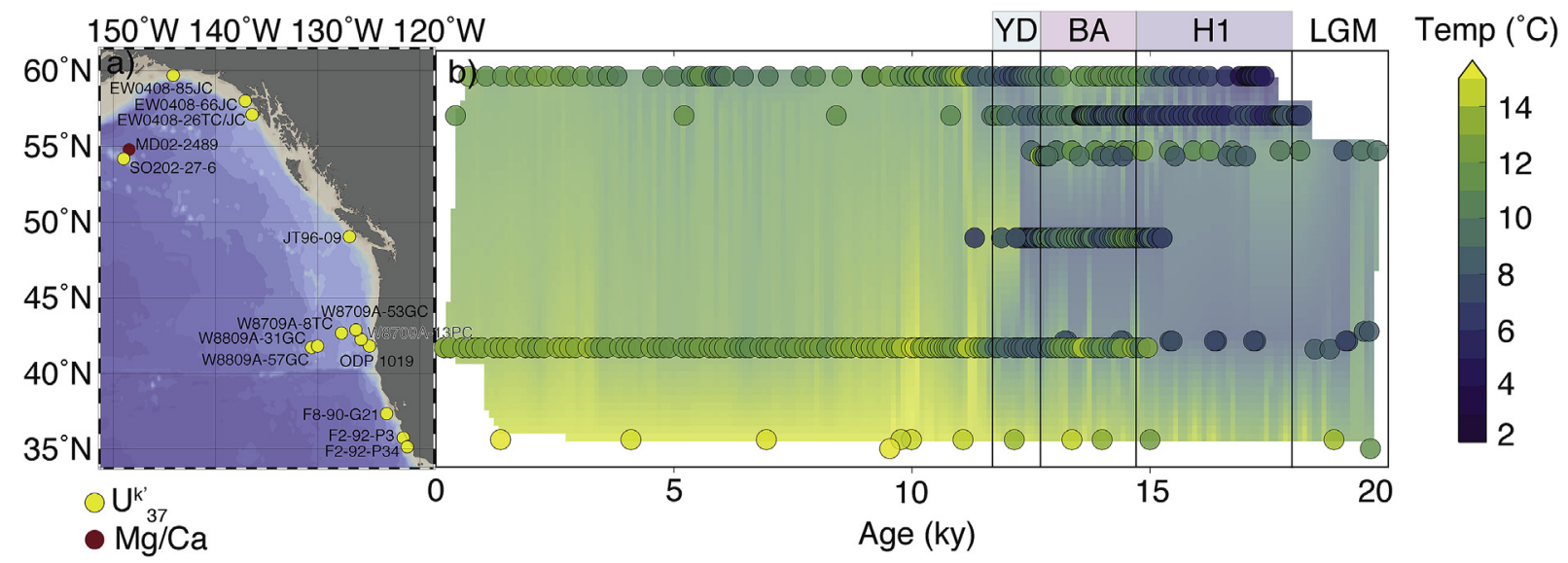

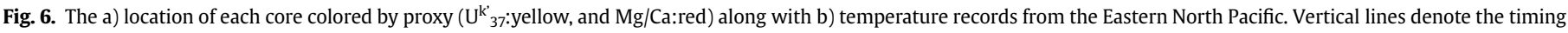

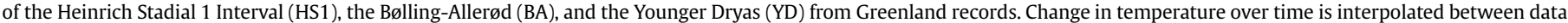
points, and latitudinally between cores. (For interpretation of the references to color in this figure legend, the reader is referred to the Web version of this article.)

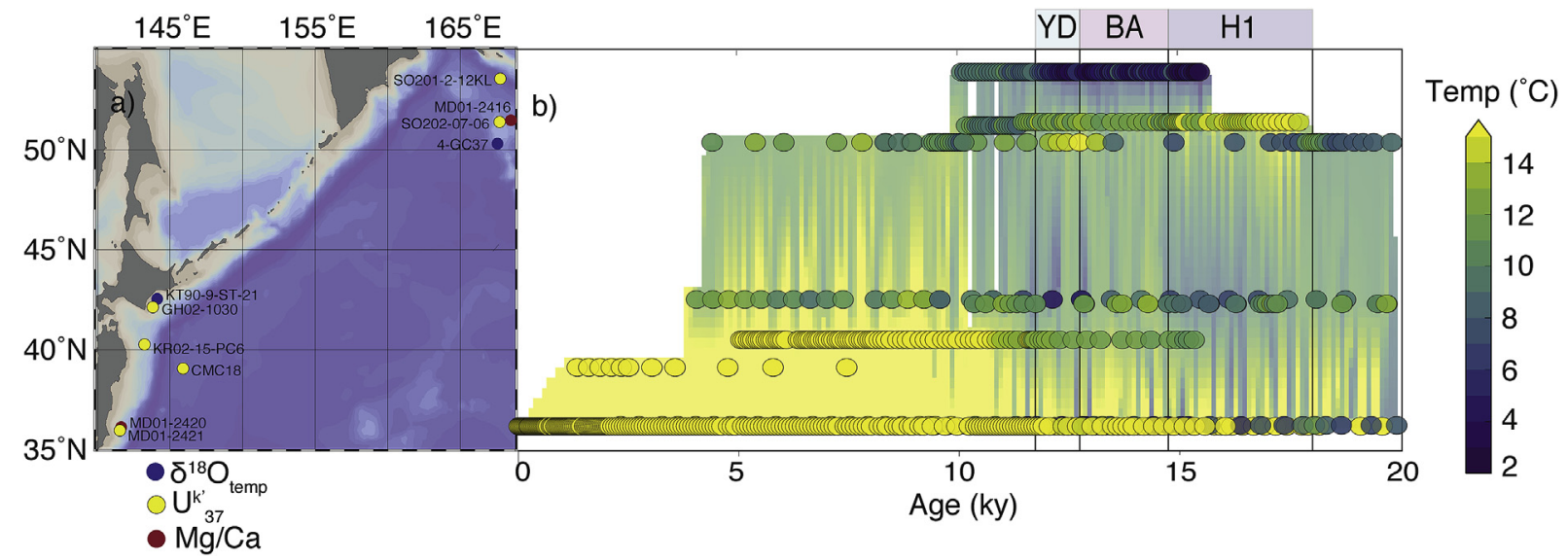

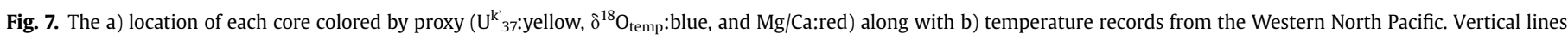

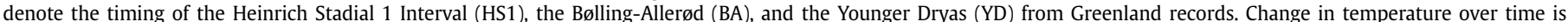

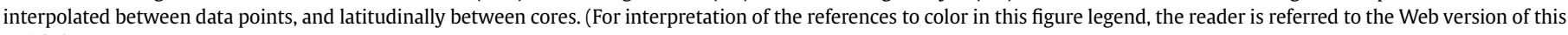
article.)

for at sites farther from the regional $\delta^{18} \mathrm{O}_{\text {seawater }}$ record generated at GGC-15. This would result in apparently muted deglacial temperature changes in $\delta^{18} \mathrm{O}_{\text {temp }}$ records. Thus, the reversed direction of SST change from that observed across much of the North Pacific is consistent with freshwater inputs during the deglaciation, with runoff during warming intervals (Bølling-Allerød and the early Holocene) resulting in sea surface cooling and freshening. This would account for the observation of cooler $\mathrm{U}^{\mathrm{k}^{\prime}} 37$ during rapid warming, associated with an increase in cold freshwater in the summer/fall, and limited variability in $\delta^{18} \mathrm{O}_{\text {temp }}$ in the same intervals, as cool temperatures compete with fresher conditions.

Where proxies disagree in the early-mid Holocene, we infer a stratified near-surface environment in the Sea of Okhotsk. Notably, the timing of a return to agreement between alkenone and $\delta^{18} \mathrm{O}_{\text {temp }}$ proxies coincides with large-scale environmental changes in Sea of Okhotsk ventilation and near-surface stratification at $\sim 6$ ka (Seki et al., 2004; Lembke-Jene et al., 2018, Fig. 5). It is likely that the early to mid Holocene trend in $\delta^{18} \mathrm{O}_{\text {temp }}$ reflects a relative freshening of the near-surface environment following a period of strong salinity stratification. As mixing increased in the mid-Holocene, the highly saline sub-surface lens either dissipated, mixing with Amur river discharge, or the reduction in stratification allowed foraminifera to migrate out of a dicothermal habitat. This is in agreement with models predicting a relatively cool, fresh deglaciation, and a decrease in near surface stratification in the more recent Holocene (Okazaki et al., 2005).

\subsection{Subpolar North Pacific}

\subsubsection{The Eastern Pacific margin deglaciation}

This synthesis reaffirms the presence of the major Northern Hemisphere deglacial features and maintained latitudinal gradient along the Eastern Pacific from $35^{\circ} \mathrm{N}$ to the Gulf of Alaska. Records from across the region are largely coherent despite spanning a substantial latitudinal gradient. While the California margin may have begun warming from a true glacial minimum many thousands of years prior to the deglaciation (Herbert et al., 2001), records from across the Eastern Pacific show a relatively cool Last Glacial Maximum and Heinrich Stadial 1. Warming is present at the onset of both the Bølling-Allerød and the Holocene, punctuated by a cool period coincident with the Younger Dryas in all cores with sufficient resolution (Fig. 6; Supplemental Fig. 5). Praetorius and Mix (2014) find a strong correlation between $\delta^{18} \mathrm{O}$ in the Gulf of Alaska and Greenland ice records through the deglaciation (16-11 
ka), and Praetorius et al. (2015) note the onset of warming at EW0408-85JC prior to the Bølling-Allerød, a trend which is also apparent at gyre site MD02-2489. Core MD02-2489 is noteworthy as the only site to show a consistently warm Heinrich Stadial 1, and the only $\mathrm{Mg} / \mathrm{Ca}$ record included in this region (Supplementary Fig. 6).

\subsubsection{The Western Pacific margin deglaciation}

Temperature changes in much of the Western North Pacific are extremely similar to the Eastern Pacific through the deglaciation, and show many of the same features. For example, MD01-2421, MD01-2420, GH02-1030, 4-GC37, and KT-9-ST-21 all warm during the Bølling-Allerød compared to previous temperatures and all but 4-GC37 then cool somewhat during the Younger Dryas (Fig. 7; Supplementary Fig. 6). The clear exception is coastal site KR02-15PC6 which appears to warm continuously from Heinrich Stadial 1 into the Holocene after a markedly warm Last Glacial Maximum. The timing of warming at both the Bølling-Allerød and the onset of the Holocene varies between sites, with some sites warming in line with North Atlantic events (KT-9-ST-21) and others apparent lagging by several hundred years (MD01-2420), although whether this is an artifact of uncertainty in dating remains unclear.

The positions of the Kuroshio and Kuroshio Extension Currents have migrated during glacial-interglacial cycles (Gallagher et al., 2015 and references therein). Along the Japan margin, SST and $\delta^{18} \mathrm{O}$ shifts at site MD01-2420 have been attributed to latitudinal migration of the Kuroshio/Oyashio current interface, with cooler temperatures in the interglacial representing a southward shifted interface, and warmer Holocene SSTs, a northward shifted interface (Sagawa et al., 2006). A gradual increase in SST in the early Holocene at MD01-2420, as well as at coastal sites GH01-1030 and KR02-15-PC6, indicates a regional signal not captured in gyre cores, and probably reflects an increased influence of the Kuroshio Current along the Japan Margin and through the Tsugaru Strait (Sagawa et al., 2006; Kuroyanagi et al., 2006; Minoshima et al., 2007a, Fig. 7). If so, we can conclude that the warm influence of the Kuroshio Current did not reach Japan margin sites above $35^{\circ} \mathrm{N}$ until the onset of the Holocene (Fig. 7).

\subsubsection{Holocene shifts in the North Pacific gyre}

Along the Eastern Pacific margin, changes in the strength of the southward flowing California Current have been marked through the Holocene by changes in SST (Barron et al., 2003; Differnbaugh et al., 2003; Barron and Anderson, 2010) and diatom abundances (Barron and Bukry, 2007). In the records reviewed here, a Holocene SST minimum from $\sim 4$ to $9 \mathrm{ka}$ is seen at several sites along the California Current, including high-resolution site ODP 1019, but also north of the California Current along the Canadian (JT96-09) and Alaskan (EW0408-85JC) margins (Fig. 6; Supplementary Fig. 5). This is in contrast to a Holocene SST maximum seen in the Western Pacific along the Japan margin during the same interval, most clearly visible at sites MD01-2420, MD01-2421, KR02-15-PC6, and KT90-9-ST-21, but not in the Western Pacific Gyre (Fig. 7; Supplementary Fig. 7). This mid-Holocene interval is followed by a warming at $\sim 4 \mathrm{ka}$ in the Eastern Pacific and concurrent cooling in the Western Pacific continuing into the modern (Figs. 5-7).

Yamamoto (2009) proposed a North Pacific east-west seesaw through the last two glacial cycles, associated with more or less El Niño-like states, with the 4 ka "Pulleniatina Minimum Event" (Ujiie et al., 2003) as one example. The proposed seesaw dynamic is associated with changes from the tropics to mid-latitudes, and is driven along the Japan and California margins by a change in gyre circulation strength or position (Timmermann et al., 2004; Ujiie et al., 2003; Yamamoto, 2009), and potentially a change in El
Niño Southern Oscillation variability or spatial expression (i.e., Tudhope et al., 2001; Moy et al., 2002; Koutavas et al., 2006; Koutavas and Joanides, 2012; Karamperidou et al., 2015). As the western marginal expression of the North Pacific Gyre was located south of $35^{\circ} \mathrm{N}$ before the early Holocene, such a seesaw dynamic would not be obvious at the latitudes of this study, prior to the Holocene. However, it could explain much of the observed Holocene contrast in SST trend between the Eastern and Western Pacific (Fig. 5). It is worth noting that the mid-Holocene SST minimum in the Eastern Pacific is present at latitudes well above that of gyre circulation in the Eastern Pacific, while records from the Western Pacific gyre do not appear to record this trend.

\subsection{Evolution of Subarctic North Pacific SST since the Last Glacial Maximum}

The Last Glacial Maximum, as recorded by proxies other than $\mathrm{U}^{\mathrm{k}^{\prime}} 37$ was colder than recent throughout the Subarctic North Pacific. The earliest warming is recorded in the Bering Sea, where by $19 \mathrm{ka}$, SST in the southern Bering Sea had increased to levels associated with the Holocene, a feature not reflected in the rest of the North Pacific. By $16 \mathrm{ka}$, early warming is present at several cores along the Eastern Pacific margin as well as in the Sea of Okhotsk. Evidence for rapid warming is present along both the Eastern and Western margins of the Pacific coincident with the Bølling-Allerød, followed by a return to near-glacial temperatures during the Younger Dryas. While rapid fluctuations in temperature are present across the Bering Sea, a clear and cohesive signal of warming over previous conditions is absent, although most sites demonstrate cooling during the Younger Dryas relative to the Bølling-Allerød. Sea of Okhotsk SSTs are also in flux through the deglaciation. However, unlike the rest of the North Pacific, the Bølling-Allerød is marked by relatively cool temperatures, likely reflecting increased freshwater input during the spring and summer. A rapid Holocene onset is reflected in SSTs in the Eastern Pacific, Bering Sea, and $\mathrm{U}^{\mathrm{k}^{\prime}}{ }_{37}$ records from the Sea of Okhotsk. Strong near-surface stratification in the Sea of Okhotsk, however, leads to apparently cool near-surface $\delta^{18} \mathrm{O}_{\text {temp, }}$, persisting until $\sim 6 \mathrm{ka}$, when enhanced mixing brings $\mathrm{U}^{\mathrm{k}^{\prime}} 37$ and $\delta^{18} \mathrm{O}_{\text {temp }}$ records into agreement. Meanwhile, along the Western Pacific margin, Holocene warming is more gradual, not reaching a maximum until $\sim 8 \mathrm{ka}$, reflecting the northernward migration of the Kuroshio Current. This northward migration of the western boundary current and strengthening of the North Pacific gyre, is reflected along the Eastern Pacific margin by a slight cooling during the mid Holocene.

\section{Conclusion}

This synthesis enables a broad description of deglacial changes in SST in the North Pacific and marginal seas. Multiple SST proxies are largely reconcilable across the North Pacific, although $\mathrm{U}^{\mathrm{k}^{\prime}}{ }_{37}$ is less reliable during cold intervals, while regional changes in $\delta^{18} \mathrm{O}_{\text {seawater }}$ may obscure $\delta^{18} \mathrm{O}_{\text {temp }}$ signals through intervals of rapid change in freshwater inputs. This source of unconstrained variability is especially relevant for the interpretation of records from the Sea of Okhotsk and Bering Sea. Records across the Eastern and Western North Pacific indicate abrupt SST shifts associated with major deglacial climate intervals (Heinrich Stadial 1, BøllingAllerød, Younger Dryas). In the Sea of Okhotsk, $\mathrm{U}^{\mathrm{k}^{\prime}} 37$ and $\delta^{18} \mathrm{O}_{\text {temp }}$ records are at odds, and the seemingly inverse relationship between proxies in the Sea of Okhotsk and the rest of the subarctic North Pacific may result from strong and variable influences of local runoff leading to changes in stratification in the basin. A warm Heinrich Stadial 1, distinct from that recorded in other North Pacific 
sites, characterizes the Bering Sea. Inconsistent SST trends between the Eastern and Western Pacific during the Holocene likely reflect the influence of a northward shifted North Pacific Gyre to latitudes above $35^{\circ} \mathrm{N}$. Future multi-proxy approaches within single cores will allow for further differentiation between, and potential corrections for proxy and region-specific confounding factors.

\section{Authors statement}

All authors have made substantial contributions to this submission. The study was conceived by CVD, SEM, and CD, data was compiled by CVD, SEM and MB, and all authors contributed to the writing of the manuscript.

\section{Declaration of competing interest}

The authors declare that they have no known competing financial interests or personal relationships that could have appeared to influence the work reported in this paper.

\section{Acknowledgements}

We would like to thank J. Barron and H. Dowsett for their comments on the manuscript, as well as two anonymous reviews. Many thanks to N. Harada for making data compilations available to us and to A. Stevenson.

\section{Appendix A. Supplementary data}

Supplementary data to this article can be found online at https://doi.org/10.1016/j.quascirev.2020.106519.

\section{References}

Alderman, S.E., 1996. Planktonic Foraminifera in the Sea of Okhotsk: Population and Stable Isotopic Analysis from a Sediment Trap. Thesis, Massachusetts Institute of Technology and Woods Hole Oceanographic Institution. https://doi.org $10.1575 / 1912 / 5673$.

Bae, S., Lee, K., Park, Y., Kimoto, K., Ikehara, K., Harada, N., 2014. Sea surface temperature and salinity changes near the Soya Strait during the last 19 ka. Quat. Int. 344, 200-210.

Barron, J.A., Anderson, L., 2010. Enhanced late Holocene ENSO/PDO expression along the margins of the eastern North Pacific. Quat. Int. 235 (1), 3-12. https:// doi.org/10.1016/j.quaint.2010.02.026.

Barron, J.A., Bukry, D., 2007. Development of the California Current during the past $12,000 \mathrm{yr}$ based on diatoms and silicoflagellates. Palaeogeogr. Palaeoclimatol. Palaeoecol. 248, 313-338.

Barron, J.A., Heusser, L., Herbert, T., Lyle, M., 2003. High-resolution climatic evolution of coastal northern California during the past 16,000 years. Paleoceanography 18 (1). https://doi.org/10.1029/2002PA000768.

Blaauw, M., Christen, J.A., 2011. Flexible paleoclimate age-depth models using an autoregressive gamma process. Bayesian Analysis 6 (3), 457-474.

Borreggine, M., Myhre, S.E., Mislan, K.A.S., Deutsch, C., Davis, C.V., 2017. A database of paleoceanographic sediment cores from the North Pacific, 1951-2016. Earth Syst. Sci. Data 9 (2), 739-749. https://doi.org/10.5194/essd-9-739-2017.

Brunelle, B.G., Sigman, D.M., Cook, M.S., Keigwin, L.D., Haug, G.H., Plessen, B. Schettler, G., Jaccard, S.L., 2007. Evidence from diatom-bound nitrogen isotopes for subarctic Pacific stratification during the last ice age and a link to North Pacific denitrification changes. Paleoceanography and Paleoclimatology 22 (10). https://doi.org/10.1029/2005PA001205.

Caissie, B.E., Brigham-Grette, J., Lawrence, K.T., Herbert, T.D., Cook, M.S., 2010. Last Glacial Maximum to Holocene sea surface conditions at Umnak Plateau, Bering Sea, as inferred from diatom, alkenone, and stable isotope records. Paleoceanography 25 (1). https://doi.org/10.1029/2008PA001671.

Childers, A.R., Whitledge, T.E., Stockwell, D.A., 2005. Seasonal and interannual variability in the distribution of nutrients and chlorophyll a across the Gulf of Alaska shelf: 1998-2000. Deep Sea Res. Part II 52 (1-2), 193-216.

Clark et al., Global climate evolution during the last deglaciation, Proc. Natl. Acad. Sci. Unit. States Am., 109(19):1134-1142, doi:10.1073/pnas.1116619109.

Cook, M.S., Keigwin, L.D., 2015. Radiocarbon profiles of the NW Pacific from the LGM and deglaciation: evaluating ventilation metrics and the effect of uncertain Gorbarenko, S.A., 1996, Stable isotope and lithologic evidence of late-glacia and Holocene oceanography of the northwestern Pacific and its marginal seas Quat. Res. 46 (3), 230-250.
Cook, M.S., Keigwin, L.D., Sancetta, C.A., 2005. The deglacial history of surface and intermediate water of the Bering Sea. Deep Sea Res. Part II 52 (16), 2163-2173.

Davies, M.H., Mix, A.C., Stoner, J.S., Addison, J.A., Jaeger, J., Finney, B., Wiest, J., 2011. The deglacial transition on the southeastern Alaska Margin: Meltwater input, sea level rise, marine productivity, and sedimentary anoxia. Paleoceanography 26 (2). https://doi.org/10.1029/2010PA002051.

Dekens, P.S., Lea, D.W., Pak, D.K., Spero, H.J., 2000. Core top calibration of Mg/Ca in tropical foraminifera: refining paleotemperature estimation. G-cubed 3 (4), 10 / 1029/2001GC000200.

Differnbaugh, N.S., Sloan, L.C., Snyder, M.A., 2003. Orbital suppression of winddriven upwelling in the California Current at $6 \mathrm{ka}$. Paleoceanography and Paleoclimatology 18 (2). https://doi.org/10.1029/2002PA000865.

Doose, H., Prahl, F.G., Lyle, M.J., 1997. Biomarker temperature estimates for modern and last glacial surface waters of the California Current system between 33 and $42^{\circ}$ N. Paleoceanography 12 (4), 615-622.

Gallagher, S.J., Kitamura, A., Iryu, Y., Itaki, T., Koizumi, I., Hoiles, P.W., 2015. The Pliocene to recent history of the Kuroshio and Tsushima Currents: a multiproxy approach. Progress in Earth and Planetary Science 2 (17). https:// doi.org/10.1186/S40645-015-0045-6.

Gardner, J.V., Dean, W.E., Dartnell, P., 1997. Biogenic sedimentation beneath the California Current system for the past $30 \mathrm{kyr}$ and its paleoceanographic significance. Paleoceanography 12 (2), 207-225.

Gebhardt, C., Kühl, N., Hense, A., Litt, T., 2008. Reconstruction of Quaternary temperature fields by dynamically consistent smoothing. Clim. Dynam. 30 (4), $421-437$.

Gorbarenko, S., Khusid, T., Basov, I., Oba, T., Southon, J., Koizumi, I., 2002. Glacial Holocene environment of the southeastern Okhotsk Sea: evidence from geochemical and palaeontological data. Palaeogeogr. Palaeoclimatol. Palaeoecol. 177 (3), 237-263.

Gorbarenko, S., Southon, J., Keigwin, L., Cherepanova, M., Gvozdeva, I., 2004. Late Pleistocene-Holocene oceanographic variability in the Okhotsk Sea: geochemical, lithological and paleontological evidence. Palaeogeogr. Palaeoclimatol. Palaeoecol. 209 (1), 281-301.

Gorbarenko, S., Basov, I., Chekhovskaya, M., Southon, J., Khusid, T., Artemova, A., 2005. Orbital and millennium scale environmental changes in the southern Bering Sea during the last glacial-Holocene: geochemical and paleontological evidence. Deep Sea Res. Part II 52 (16), 2174-2185.

Gorbarenko, S., Wang, P., Wang, R., Cheng, X., 2010. Orbital and suborbital environmental changes in the southern Bering Sea during the last 50kyr. Palaeogeogr. Palaeoclimatol. Palaeoecol. 286 (1), 97-106.

Gorbarenko, S.A., Harada, N., Malakhov, M.I., Velivetskaya, T.A., Vasilenko, Y.P., Bosin, A.A., Derkachev, A.N., Goldberg, E.L., Ignatiev, A.V., 2012. Responses of the Okhotsk Sea environment and sedimentology to global climate changes at the orbital and millennial scale during the last 350kyr. Deep Sea Res. Part II 61, 73-84.

Gorbarenko, S.A., Artemova, A.V., Goldberg, E.L., Vasilenko, Y.P., 2014. The response of the Okhotsk Sea environment to the orbital-millennium global climate changes during the Last Glacial Maximum, deglaciation and Holocene. Global Planet. Change 116, 76-90.

Gray, W.R., Rae, J.W.B., Wills, R.C.J., Shevenell, A.E., Taylor, B., Burke, A., Foster, G.L., Lear, C.H., 2018. Deglacial upwelling, productivity and $\mathrm{CO}_{2}$ outgassing in the north Pacific Ocean. Nat. Geosci. 11, 340-344.

Harada, N., Ahagon, N., Uchida, M., Murayama, M., 2004. Northward and southward migrations of frontal zones during the past $40 \mathrm{kyr}$ in the Kuroshio-Oyashio transition area. G-cubed 5, Q09004. https://doi.org/10.1029/2004GC000740.

Harada, N., Ahagon, N., Sakamoto, T., Uchida, M., Ikehara, M., Shibata, Y., 2006. Rapid fluctuation of alkenone temperature in the southwestern Okhotsk Sea during the past $120 \mathrm{ky}$. Global Planet. Change 53 (1), 29-46.

Harada, N., Sato, M., Sakamoto, T., 2008. Freshwater impacts recorded in tetraunsaturated alkenones and alkenone sea surface temperatures from the Okhotsk Sea across millennial-scale cycles. Paleoceanography 23, PA3201. https:// doi.org/10.1029/2006PA001410.

Harada, N., Sato, M., Seki, O., Timmermann, A., Moossen, H., Bendle, J., Nakamura, Y., Kimoto, K., Okazaki, Y., Nagashima, K., 2012. Sea surface temperature changes in the Okhotsk Sea and adjacent North Pacific during the last glacial maximum and deglaciation. Deep Sea Res. Part II 61, 93-105.

Harrison, P.J., Whitney, F.A., Tsuda, A., Saito, H., Tadokoro, K., 2004. Nutrient and plankton dynamics in the NE and NW gyres of the subarctic Pacific Ocean. J. Oceanogr. 60 (1), 93-117.

Haug, G.H., Ganopolski, A., Sigman, D.M., Rosell-Mele, A., Swann, G.E., Tiedemann, R., Jaccard, S.L., Bollmann, J., Maslin, M.A., Leng, M.J., 2005. North Pacific seasonality and the glaciation of North America 2.7 million years ago. Nature 433, 821-825.

Hendy, I.L., Kennett, J.P., 1999. Latest Quaternary North Pacific surface-water responses imply atmosphere-driven climate instability. Geology 27 (4), 291-294.

Herbert, T.D., Schuffert, J.D., Andreasen, D., Heusser, L., Lyle, M., Mix, A., Ravelo, A.C., Stott, L.D., Herguera, J.C., 2001. Collapse of the California Current during glacial maxima linked to cliamte change on land. Science 293 (71), 78.

Hill, T.M., Kennett, J.P., Pak, D.K., Behl, R.J., Robert, C., Beaufort, L., 2006. Pre-Bølling warming in Santa Barbara Basin, California: surface and intermediate water records of early deglacial warmth. Quat. Sci. Rev. 25, 2835-2845.

Hönisch, B., Allen, K.A., Lea, D.W., Spero, H.J., Eggins, S.M., Arbuszewski, J., Rosenthal, Y., Russell, A.D., Elderfield, H. 2013. The influence of salinity on Mg/ $\mathrm{Ca}$ in planktic foraminifers: evidence from cultures, core-top sediments and complementary $\delta^{18} \mathrm{O}$. Geochem. Cosmochim. Acta 121, 196-213. 
Ikehara, K., Ohkushi, K., Shibahara, A., Hoshiba, M., 2006. Change of bottom water conditions at intermediate depths of the Oyashio region, NW Pacific over the past 20,000 yrs. Global Planet. Change 53 (1), 78-91.

Ishiwatari, R., Houtatsu, M., Okada, H., 2001. Alkenone-sea surface temperatures in the Japan Sea over the past 36 kyr: warm temperatures at the last glacial maximum. Org. Geochem. 32, 57-67.

Isono, D., Yamamoto, M., Irino, T., Oba, T., Murayama, M., Makamura, T., Kawahata, H., 2009. The 1500-year climate oscillation in the midlatitude North Pacific during the Holocene. Geology 37 (7), 591-594. https://doi.org/10.1130/ G25667A.1.

Karamperidou, C., Di Nezio, P.N., Timmermann, A., Jin, F., Cobb, K.M., 2015. The response of ENSO flavors to mid-Holocene climate: implications for proxy interpretation. Paleoceanography and Paleoclimate 30 (5), 527-547. https:/ doi.org/10.1002/2014PA002742.

Keigwin, L.D., 1998. Glacial-age hydrography of the far northwest Pacific Ocean. Paleoceanography 13 (4), 323-339.

Kiefer, T., Kienast, M., 2005. Patterns of deglacial warming in the Pacific Ocean: a review with emphasis on the time interval of Heinrich event 1. Quaternary Science Reveiws 24, 1063-1081.

Kiefer, T., Sarnthein, M., Erlenkeuser, H., Grootes, P.M., Roberts, A.P., 2001. North Pacific response to millennial-scale changes in ocean circulation over the last 60 kyr. Paleoceanography and Paleoclimatology 16 (2), 179-189.

Kienast, S.S., McKay, J.L., 2001. Sea surface temperatures in the subarctic Northeast Pacific reflect millennial-scale climate oscillations during the last 16 kyrs. Geophys. Res. Lett. 28 (8), 1563-1566.

Koutavas, A., Joanides, S., 2012. El niño-southern oscillation extrema in the Holocene and last glacial maximum. Paleoceanography 27, PA4208. https://doi.org/ 10.1029/2012PA002378.

Koutavas, A., deMenocal, P.B., Olive, G.C., Lynch-Stieglitz, J., 2006. Mid-Holocene El Niño-Southern Oscillation (ENSO) attenuation revealed by individual foraminifera in eastern tropical Pacific sediment. Geology 34 (12), 993-996.

Kuehn, H., Lembke-Jene, L., Gersonde, R., Esper, O., Lamy, F., Arz, H., Kuhn, G., Tiedemann, R., 2014. Laminated sediments in the Bering Sea reveal atmospheric teleconnections to Greenland climate on millennial to decadal timescales during the last deglaciation. Clim. Past 10, 2215-2236.

Kuroyanagi, A., Kawahata, H., Narita, H., Ohkushi, K., Aramaki, T., 2006. Reconstruction of paleoenvironmental changes based on the planktonic foraminiferal assemblages off Shimokita (Japan) in the northwestern North Pacific. Global Planet. Change 53, 92-107.

Laurindo, L., Mariano, A., Lumpkin, R., 2017. An improved near-surface velocity climatology for the global ocean from drifter observation. Deep-Sea Res. I 124, 73-92.

Lea, D.W., Mashiotta, T.A., Spero, H.J., 1999. Controls on magnesium and strontium uptake in planktonic foraminifera determined by live culturing. Geochem. Cosmochim. Acta 63 (16), 2369-2379.

Lembke-Jene, L., Tiedemann, R., Nurnberg, D., Kokfelt, U., Kozden, R., Max, L., Rohl, U., Gorbarenko, S.A., 2017. Deglacial variability in Okhotsk Sea intermediate water ventilation and biogeochemistry: implications for North Pacific nutrient supply and productivity. Quat. Sci. Rev. 160, 116-137. https://doi.org/ 10.1016/j.quascirev.2017.01.016.

Li, F., Wang, H., 2014. Autumn Eurasian snow depth, autumn Arctic sea ice cover and East Asian winter monsoon. Int. J. Climatol. 34 (13), 3616-3625.

Locarnini, R., Mishonov, A., Antonov, J., Boyer, T., Garcia, H., Baranova, O., Zweng, M., Paver, C., Reagan, J., Johnson, D., 2013. World ocean atlas 2013, volume 1: temperature. NOAA Atlas NESDIS 73, 40.

Lopes, C., Mix, A.C., 2009. Pleistocene megafloods in the northeast Pacific. Geology 37 (1), 79-82.

Maier, E., Zhange, X., Abelmann, A., Gersonde, R., Mulitza, S., Werner, S., Wener, M., Meheust, M., Ren, J., Chapligin, B., Meyer, H., Stein, R., Tiedemann, R., Lohmann, G., 2018. North Pacific freshwater events linked to changes in glacial ocean ciculation. Nature 559, 241-245.

Martin, S., Drucker, R., Yamashita, K., 1998. The production of ice and dense shelf water in the Okhotsk Sea polynyas. J. Geophys. Res. 103, 27771-27782.

Mashiotta, T.A., Lea, D.W., Spero, H.J., 1999. Glacial-interglacial changes in Subantarctic sea surface temperature and $\delta^{18} \mathrm{O}$-water using foraminfieral $\mathrm{Mg}$. Earth Planet Sci. Lett. 170 (4), 417-432.

Max, L., Riethdorf, J.R., Tiedemann, R., Smirnova, M., Lembke-Jene, L., Fahl, K., Nürnberg, D., Matul, A., Mollenhauer, G., 2012. Sea surface temperature variability and sea-ice extent in the subarctic northwest Pacific during the past 15,000 years. Paleoceanography 27, PA3213. https://doi.org/10.1029/ 2012PA002292.

Méheust, M., Fahl, K., Stein, R., 2013. Variability in modern sea surface temperature, sea ice and terrigenous input in the sub-polar North Pacific and Bering Sea: Reconstruction from biomarker data. Org. Geochem. 57, 54-64. https://doi.org/ 10.1016/j.orggeochem.2013.01.2008.

Méheust, M., Stein, R., Fahl, K., Gersonde, R., 2018. Sea-ice variability in the subarctic North Pacific and adjacent Bering Sea during the past $25 \mathrm{ka}$ : new insights from $\mathrm{IP}_{25}$ and $\mathrm{U}^{\mathrm{k}} 37$ proxy records. Arktos 4 (8). https://doi.org/10.1007/s41063-0180043-1.

Minoshima, K., Kawahata, H., Ikehara, K., 2007a. Changes in biological production in the mixed water region (MWR) of the northwestern North Pacific during the last 27 kyr. Palaeogeogr. Palaeoclimatol. Palaeoecol. 254 (3), 430-447.

Minoshima, K. Kawahata, H., Irino, T., Ikehara, K., Aoki, K., Uchida, M., Yoneda, M. Shibata, Y., 2007b. Deep water ventilation in the northwestern North Pacific during the last deglaciation and the early Holocene (15-5cal. kyrB. P.) based on
AMS ${ }^{14} \mathrm{C}$ dating. Nucl. Instrum. Methods Phys. Res. Sect. B Beam Interact. Mater. Atoms 259 (1), 448-452.

Miura, T., Suga, T., Hanawa, K., 2002. Winter mixed layer and formation of dichothermal water in the Bering Sea. J. Oceanogr. 58, 815-823.

Mix, A.C., Lund, D.C., Pisias, N.G., Boden, P., Bornmalm, L., Lyle, M., Pike, J., 1999. Rapid climate oscillations in the northeast Pacific during the last deglaciation reflect Northern and Southern Hemisphere sources. In: Clark, P.U., Webb, R.S., Keigwin, L.D. (Eds.), Mechanisms of Global Change at Millennial Time Scales, Washington, DC.

Mochizuki, M., Shiga, N., Saito, M., Imai, K., Nojiri, Y., 2002. Seasonal changes in nutrients, chlorophyll a and the phytoplankton assemblage of the western subarctic gyre in the Pacific Ocean. Deep Sea Res. Part II 49 (24), 5421-5439.

Moy, C.M., Seltzer, G.O., Rodbell, D.T, Anderson, D.M., 2002. Variability of El niño/ southern oscillation activity at millennial timescales during the Holocene epoch. Nature 420, 162-165.

Müller, P.J., Kirst, G., Ruhland, G., Von Storch, I., Rosell-Melé, A., 1998. Calibration of the alkenone paleotemperature index UK'37 based on core-tops from the eastern South Atlantic and the global ocean $\left(60^{\circ} \mathrm{N}-60^{\circ} \mathrm{S}\right)$. Geochem. Cosmochim. Acta 62 (10), 1757-1772.

Nürnberg, D., Bijma, J., Hemleben, C., 1996. Assessing the reliability of magnesium in foraminiferal calcite as a proxy for water mass temperatures. Geochem. Cosmochim. Acta 60, 803-814. https://doi.org/10.1016/0016-7037(95)00446-7.

Nürnberg, D., Dethleff, D., Tiedemann, R., Kaiser, A., Gorbarenko, S.A., 2011. Okhotsk Sea ice coverage and Kamchatka glaciation over the last 350ka-evidence from ice-rafted debris and planktonic $\delta^{18} \mathrm{O}$. Palaeogeogr. Palaeoclimatol. Palaeoecol. 310 (3), 191-205.

Oba, T., Murayama, M., 2004. sea-surface temperature and salinity changes in the northwest pacific since the last glacial maximum. J. Quat. Sci. 19 (4), 335-346. https://doi.org/10.1002/jqs.843.

Oba, T., Irino, T., Yamamoto, M., Murayama, M., Takamura, A., Aoki, K., 2006. Paleoceanographic change off central Japan since the last 144,000 years based on high-resolution oxygen and carbon isotope records. Global Planet. Change 53, $5-20$.

Okazaki, Y., Sagawa, T., Asahi, H., Horikawa, K., Onodera, J., 2012. Ventilation changes in the western North Pacific since the last glacial period. Clim. Past 8 (1), 17-24.

Okazaki, Y., Kimoto, K., Asahi, H., Sato, M., Nakamura, Y., Harada, N., 2014. Glacial to deglacial ventilation and productivity changes in the southern Okhotsk Sea. Palaeogeogr. Palaeoclimatol. Palaeoecol. 395, 53-66.

Ortiz, J., Mix, A., Hostetles, S., Kashgarian, M., 1997. The California current of the last glacial maximum: reconstruction at $42^{\circ} \mathrm{N}$ based on multiple proxies. Paleoceanography 12 (2), 191-205. https://doi.org/10.1029/96PA03165.

Pagani, M., 2002. The alkenone- $\mathrm{CO}_{2}$ proxy and ancient atmospheric carbon dioxide. Phil. Trans. Roy. Soc. Lond. 360 (1793), 609-632.

Pelland, N.A., Eriksen, C.C., Cronin, M.F., 2016. Seaglider surveys at ocean station papa: circulation and water mass properties in a meander of the north pacific current. J. Geophys. Res. 121 (9), 6816-6846.

Pelto, B.M., Caissie, B.E. Petsch, S.T., Brigham-Grette, J., 2018. Oceanographic and climatic change in the Bering Sea, last glacial maximum to Holocene. Paleoceanography and Paleoclimatology 33, 93-111.

Pisias, N.G., Mix, A.C., Heusser, L., 2001. Millennial scale cliamte variability of the northeast Pacific Icean and northwest North America based on radiolaria and pollen. Quat. Sci. Rev. 20, 1561-1576.

Praetorius, S.K., Mix, A.C., 2014. Synchronization of North Pacific and Greenland climates preceded abrupt deglacial warming. Science 345 (6195), 444-448.

Praetorius, S., Mix, A., Walczak, M., Wolhowe, M., Addison, J., Prahl, F., 2015. North Pacific deglacial hypoxic events linked to abrupt ocean warming. Nature 527 (7578), 362-366.

Praetorius, S., Mix, A., Jensen, B., Froese, D., Milne, G., Wolhowe, M., Addison, J., Prahl, F., 2016. Interaction between climate, volcanism, and isostatic rebound in Southeast Alaska during the last deglaciation. Earth Planet Sci. Lett. 452, 79-89.

Prahl, F.G. Muehlhausen, L.A., Zahnle, D.L., 1998. Further evaluation of long- chain alkenones as indicators of paleoceano- graphic conditions. Geochem. Cosmochim. Acta 52, 2303-2310.

Rae, J.W.B., Sarnthein, M., Foster, G.L., Ridgwell, A., Grootes, P.M., Elliot, T., 2014 Deep water formation in the North Pacific and deglacial $\mathrm{CO}_{2}$ rise. Paleoceanography and Paleoclimatology 29 (6), 645-667.

Rasmussen, S.O., Bigler, M., Blockley, S.P., Blunier, T., Buchardt, S.L., Clausen, H.B. Cvijanovic, I., Dahl-Jenson, D., Johnsen, S.J., Fischer, H., Gkinis, V., Guillevic, M., Hoek, W.Z., Lowe, J.J., Pedro, J.B., Popp, T., Seierstad, I.K., Steffensen, J.P. Svensson, A.M., Vallelonga, P., Vinther, B.M., Walker, M.J.C., Wheatley, J.J. Winstrup, M., 2015. A stratigraphic framework for abrupt climatic changes during the Last Glacial period based on three synchronized Greenland ice-core records: refining and extending the INTIMATE event stratigraphy. Quat. Sci. Rev. 106 (15), 14-28.

Regenberg, M., Steph, S., Nürnberg, D., Tiedemann, R., Garbe-Schönberg, D., 2009. Calibrating $\mathrm{Mg} / \mathrm{Ca}$ ratios of multiple planktonic foraminiferal species with 180-calcification tempertures: paleothermometry for the upper water column. Earth Planet Sci. Lett. 278, 324-336.

Regenberg, M., Regenberg, A., Garbe-Schönberg, Lea, D.W., 2014. Global distribution effects on planktonic foraminiferal $\mathrm{Mg} / \mathrm{Ca}$ ratios controlled by the calcitesaturation state of bottom waters. Paleoceanography 29, 127-142. https:/ doi.org/10.1002/2013PA002492.

Reimer, P.J., Bard, E., Bayliss, A., Beck, J.W., Blackwell, P.G., Ramsey, C.B., Buck, C.E. Cheng, H., Edwards, R.L., Friedrich, M., Groots, P.M., Guilderson, T.P. 
Haflidason, H., Hajdas, I., Hatte, C., Heaton, T.J., Hoffman, D.L., Hogg, A.G., Hughen, K.A., Kaiser, K.F., Kromer, B., Manning, S.W., Niu, M., Reimer, R.W., Richards, D.A., Scott, E.M., Southon, J.R., Staff, R.A., Turney, C.S.M., van de Plicht, J., 2013. IntCal13 and Marine13 radiocarbon age calibration curves 050,000 years cal BP. Radiocarbon 55 (4), 1869-1887.

Riethdorf, J. Max, L., Nurnberg. D., Lembke-Jene, L., Tiedemann, R., 2013. Deglacia development of (sub) sea surface temperature and salinity in the subarctic northwest Pacific: implications for upper-ocean stratificiaiton. Paleoceanography and Paleoclimatology 28 (1), 91-104.

Roden, G.I., 1995. Aleutian Basin of the Bering Sea: thermohaline, oxygen, nutrient, and current structure in july 1993. J. Geophys. Res. 100, 13539-13554.

Rosell-Mele, A., 1998. Interhemispheric appraisal of the value of alkenone indices as temperature and salinity proxies in high-latitude locations. Paleoceanography 13 (6), 694-703.

Russell, A.D., Hönisch, B., Spero, H.J., Lea, D.W., 2004. Effects of seawater carbonate ion concentration and temperature on shell $\mathrm{U}, \mathrm{Mg}$, and $\mathrm{Sr}$ in cultured planktonic foraminifera. Geochem. Cosmochim. Acta 68 (21), 4347-4361.

Sagawa, T., Toyoda, K., Oba, T., 2006. Sea surface temperature record off centra Japan since the Last Glacial Maximum using planktonic foraminiferal $\mathrm{Mg} / \mathrm{Ca}$ thermometry. J. Quat. Sci. 21 (1), 63-73.

Sancetta, C., 1983. Effect of pleistocene glaciation upon oceanographic characteristics of the north Pacific Ocean and Bering Sea. Deep Sea Res. Part I 30 (8) 851-869.

Sarnthein, M., Kiefer, T., Grootes, P.M., Elderfield, H., Erlenkeuser, H., 2006. Warmings in the far northwestern Pacific promoted pre-Clovis immigration to America during Geinrich event 1. Geology 34 (3), 141-144.

Schlung, S.A., Christina Ravelo, A., Aiello, I.W., Andreasen, D.H., Cook, M.S. Drake, M., Dyez, K.A., Guilderson, T.P., LaRiviere, J.P., Stroynowski, Z., 2013. Millennial-scale climate change and intermediate water circulation in the Bering Sea from 90 ka: a high-resolution record from IODP Site U1340. Paleoceanography 28 (1), 54-67.

Seki, O., Ishiwatari, R., Kohei, M., 2002. Millennial climate oscillations in NE Pacific surface waters over the last $82 \mathrm{kyr}$ : new evidence from alkenones. Geophys. Res. Lett. 29 (23), 2144. https://doi.org/10.1029/2002GL015200.

Seki, O., Kawamura, K., Ikehara, M., Nakatsuka, T., Oba, T., 2004. Variation of alkenone sea surface temperature in the Sea of Okhotsk over the last 85 kyrs. Org Geochem. 35 (3), 347-354.

Seki, O., Sakamoto, T., Sakai, S., Schouten, S., Hopmans, E.C., Sinninghe Damste, J.S. Pancost, R.D., 2009. Large changes in seasonal sea ice distribution and productivity in the Sea of Okhotsk during the deglaciations. G-cubed 10 (10). https://doi.org/10.1029/2009GC002613.

Serno, S., Winckler, G., Anderson, R.F., Maier, E., Ren, H., Gersonde, R., Haug, G.H. 2015. Comparing dust flux records from the Subarctic North Pacific and Greenland: implications for atmospheric transport to Greenland and for the application of dust as a chronostratigraphic tool. Paleoceanography and Paleocliamtology 30 (6), 583-600.

Shackleton, N., 1974. Attainment of isotopic equilibrium between ocean water and the benthonic foraminifera genus Uvigerina: isotopic changes in the ocean during the last glacial, 219. Colloques Internationaux de CNRS, pp. 203-209.

Sikes, E.L., Volkman, J.K., Robertson, L.G., Pichon, J.J., 1997. Alkenones and alkenes in surface waters and sediments of the Southern Ocean: implications for paleotemperature estimation in polar regions. Geochem. Cosmochim. Acta 61 (7), 1495-1505.

Stabeno, P., Ladd, C., Reed, R., 2009. Observations of the aleutian north slope current, Bering Sea, 1996-2001. J. Geophys. Res. 114, C05015. https://doi.org/ 10.1029/2007JC004705.

Talley, L.D., 1991. An Okhotsk Sea water anomaly: implications for ventilation in the North Pacific. Deep Sea Res. Part I 38, S171-S190. https://doi.org/10.1016/ S0198-0149(12)80009-4.

Ternois, Y., Kawamura, K. Ohkouchi, N., Keigwin, L, 2000. Alkenone sea surface temperature in the Okhotsk Sea for the last 15 kyr. Geochem. J. 34 (4), 283-293.

Timmermann, A., Justino, F., Jin, F.-F., Krebs, U., Goosse, H., 2004. Surface temperature control in the North and tropical Pacific during the last glacial maximum. Clim. Dynam. 23, 353-370. https://doi.org/10.1007/S00382-004-0434-9.

Tsurushima, N., Nojiri, Y., Imai, K., Watanabe, S., 2002. Seasonal variations of carbon dioxide system and nutrients in the surface mixed layer at station KNOT ( $44^{\circ} \mathrm{N}$, $155^{\circ}$ E) in the subarctic western North Pacific. Deep Sea Res. Part II 49 (24), 5377-5394.

Tudhope, A.W., Chilcott, C.P., CmCulloch, M.T., Cook, E.R., Chappell, J., Ellam, R.M., Lea, D.W., Lough, J.M., Shimmield, G.B., 2001. Variability in the El niño-southern oscillation through a glacial-interglacial cycle. Science 291 (5508), 1511-1517.

Ujiie, Y., Ujiie, H., Taira, A., Nakamura, T., Oguri, K., 2003. Spatial and temporal variability of surface water in the Kuroshio source region, Pacific Ocean, over the past 21,000 years: evidence from planktonic foraminifera. Mar. Micropaleontol. 49, 335-364.

Warner, M.J., Bullister, J., Wisegarver, D., Gammon, R., Weiss, R., 1996. Basin-wide distributions of chlorofluorocarbons CFC-11 and CFC-12 in the north pacific: 1985-1989. Jounral of Geophysical Research 101 (20), 525-520.

Yamamoto, M., 2009. Response of mid-latitude North Pacific surface temperatures to orbital forcing and linkage to the East Asian summer monsoon and tropical ocean-atmosphere interactions. J. Quat. Sci. 24 (8), 836-847. https://doi.org/ 10.1002/PQS.1255

Yamamoto, M., Oba, T., Shimamune, J., Ueshima, T., 2004. Orbital-scale anti-phase variation of sea surface temperature in mid-latitude North Pacific margins during the last 145,000 years. Geophys. Res. Lett. 31, L16311. https://doi.org/ 10.1029/2004GL020138.

Yamamoto, M., Shimamoto, A., Fukuhara, T., Naraoka, H., Tanaka, Y., Nishimura, A. 2007. Seasonal and depth variations in molecular and isotopic alkenone composition of sinking particles from the western. North Pacific 54 (9), 1571-1592.

Zheng, Y., Geen, A., Anderson, R.F., Gardner, J.V., Dean, W.E., 2000. Intensification of the northeast pacific oxygen minimum zone during the bølling-allerød warm period. Paleoceanography 15 (5), 528-536. https://doi.org/10.1029/ 2003PA000979. 